\title{
Alaksiej Šałanda
}

Instytut Historii Narodowej Akademii Nauk Białorusi w Mińsku

\section{Sąd grodzki grodzieński za czasów Wazów (1587-1668): stan badań i źródła}

\section{Zarys treści}

W artykule przedstawiono - na podstawie źródeł zachowanych w archiwach Białorusi, Litwy i Polski - proces sądowy w grodzie grodzieńskim na podstawie III Statutu Wielkiego Księstwa Litewskiego z 1588 r., przyczyny nieregularnych grodzkich sesji sądowych (roczków), skład grodu i przebieg kariery urzędników grodzkich grodzieńskich, zagadnienie finansowania starostów sądowych, tworzenie i funkcjonowanie kancelarii grodzkiej i archiwum, udział miejscowych urzędników grodzkich w kapturach z lat 1634, 1648 i 1668, działania nadzwyczajnego sądu compositi iudicii w 1658 r. pod okupacją moskiewską, wznowienie działalności grodu po wyzwoleniu Grodna i powiatu spod władzy wojsk moskiewskich w $1661 \mathrm{r}$.

\begin{abstract}
The article - based on a collection of sources preserved in the archives of Belarus, Lithuania and Poland - presents the following problems of the Grodno castle court proceedings: the judicial process based on the Third Statute of the Grand Duchy of Lithuania of 1588, the causes of irregular castle court sessions (roczki), the composition and the careers of Grodno castle court officials, the problem of financing of the castle starosts, the creation and functioning of a castle court chancellery and archive, the participation of local castle court officials in the so-called hooded courts (sady kapturowe) in 1634, 1648, and 1668, the operation of the extraordinary court of compositi iudicii in 1658 under the Muscovite occupation, the resumption of the castle court activity after the liberation of Grodno (Hrodna) and its district (powiat) from the Muscovite army in 1661.
\end{abstract}

Słowa kluczowe: Wielkie Księstwo Litewskie, sąd grodzki grodzieński, III Statut Wielkiego Księstwa Litewskiego z 1588 r., grodzkie sesje sądowe (roczki), kancelaria i archiwum grodzkie, sąd compositi iudicii

Key words: Grand Duchy of Lithuania, Grodno castle court, Third Statute of the Grand Duchy of Lithuania in 1588, castle court sessions (roczki), castle court chancellery and archive, court of compositi iudicii

Poruszony w niniejszym artykule problem stanowi kontynuację prowadzonych w latach 2009-2012 badań nad działalnością sądu zamkowego i grodzkiego 
powiatu grodzieńskiego w drugiej połowie XV w. do 1586 r. ${ }^{1}$ Ze względu na szczupłość źródeł ukazanie funkcjonowania sądu grodzkiego powiatu grodzieńskiego z lat 1587-1668 napotyka na poważne trudności. Księgi aktowe tej instytucji sporządzane za panowania Zygmunta III (1587-1632), Władysława IV (1632-1648) i Jana Kazimierza (1648-1668) uległy zniszczeniu podczas wojny północnej (1700-1721), gdy Grodno było zajęte przez wojska szwedzkie (1702-1705, 1706-1707, 1708) oraz moskiewskie (1705-1706, 1708, 1710-1715)2. Dotychczasowa literatura przedmiotu ocenia, że zniszczyli je żołnierze armii Piotra $\mathrm{I}^{3}$. Jednak - jak można wnioskować na podstawie zachowanych przekazów źródłowych - księgi grodzkie zostały spalone lub wywiezione przez Szwedów w 1705 r.:

jako o tym całego powiatu Grodzieńskiego protestacya eo nomine wyniesiona ratione popalenia y zabrania xiąg grodowych y aktów różnych w zamku na ten czas Grodzieńskim będących ${ }^{4}$.

Zniszczenie ksiąg grodzkich grodzieńskich odnotowano w relacji generała powiatu grodzieńskiego Jana Zapolskiego. W sierpniu 1724 r., szukając na prośbę księdza i biskupa akateńskiego Bogusława Korwina Gosiewskiego testamentu Ewy ze Świackich Cydzikowej, datowanego 1681 r., a także wieczystego listu sprzedażnego tegoż na folwark Świack Puciwlański z 1685 r., zauważył on:

przybywszy do Kancelaryey Grodzkiey Grodzienskiey byłem Sprowadzony przez JMPana Jana Franciszka Olizarowicza Namiesnika i Regenta Grodzkiego Powiatu Grodzienskiego, ad archivum akt in Collegio w Bogu Przewielebnych Jchmw XX Jezuitów Grodzienskich złozonych kędy gdym Oglądał akta tak pierwszą jako y poslednieyszą datą wyzey namienionych lat, nie nalazłem akt Jn pleno numero az do Roku Tysiąc Siedmset Szóstego, Ktore wszytkie anterioris numeri przez Jnkursyą Nieprzyiacielską Szwiecką y Moskiewską Jako Miałem Relacyą w Zamku Grodzienskim będące wszytkie do Szczentu zruynowane Jedne na ładunki Zabrane Drugie Podarte poszarpane Zostały, na dowod czego Oglądałem Niektore po Ziemi inante

\footnotetext{
${ }^{1}$ А. Шаланда, Замкавы суд у Гарадзенскім павеце (другая палова XV-1566 г.), w: Гарадзенскі палімпсест II. 2009. Дзяржаўныя ўстановы і палітычнае жыциё. XV-XX cmст., red. А. Смаленчук, Н. Сліж, Горадня 2009, s. 8-34; idem, Гродскі суд Гарадзенскага павета ВКЛ у другой палове XVI-XVII cmст. Частка I: Перадумовы, ход і вынікі рэбормы гарадзенскага замкавага суда (1562-1572 гг.), w: Гарадзенскі палімпсест III. 2010. Дзяржаўныя і сацыяльныя структуры. XVI-XX стст., red. А. Смаленчук, Н. Сліж, Мінск 2011, s. 12-44; idem, Гродскі суд Гарадзенскага павета у другой палове XVI-XVII стст. Частка II: Функцыянаванне гарадзенскага гродскага суда ў перыяд першых бескаралеўяу у 1572-1576 г2., w: Гарадзенскі палімпсест IV. 2011. Асоба, грамадства, дзяржава. XV-XX cmсm., red. А. Смаленчук, Н. Сліж, Мінск 2012, s. 112-134; idem, Гродскі суд Гарадзенскага павета ВКЛ учасы праўлення Стэфана Баторыя (1576-1586 г2.), w: Вялікае Княства Літоўскае і суседзі. Права, вайна, дыппламатья, red. С. Сокал, А. Янушкевіч, Мінск 2012, s. 44-82.

${ }^{2}$ С. Данскіх, Гродна у час Паўночнай вайны 1700-1721 г2., w: Памяць: Гіст.-дакум. хроніка горада Гродна, red. Г. Пашкоў, Я. Жабрун, I. Крэнь et al., Мінск 1999, s. 97-99.

${ }^{3}$ Ю. Гардзееў, Магдэбургская Гародня, Гародня-Wrocław 2008, s. 33.

${ }^{4}$ Акты, издаваемые Виленской археографической комиссией, t. 7, Вильна 1874, s. 425-426.
} 
usum Zabrane y teraz Sine ordine w skrzyni złożone podarte poszarpane ledwą ktorą Sztukę w całosci będąca ${ }^{5}$.

Wobec szczupłości bazy źródłowej za podstawę niniejszego studium posłużą zachowane wypisy ${ }^{6} \mathrm{z}$ ksiąg grodzkich grodzieńskich z poszczególnych lat, zawierające aktykacje spraw, dokumentów, kwitów, relacji, oświadczeń, oryginalne pozwy sądowe, pisma urzędowe, ceduły i zapisy, na które udało się natrafić w różnorodnych placówkach archiwalnych oraz muzealnych Białorusi, Litwy i Polski. Pokaźną ilość takich materiałów odkryto w Narodowym Archiwum Historycznym Białorusi w Mińsku ${ }^{7}$, Narodowym Archiwum Historycznym Białorusi w Grodnie ${ }^{8}$ oraz kolekcji rękopisów Grodzieńskiego Państwowego Muzeum Historyczno-Archeologicznego9. Podczas kwerend archiwalnych w Narodowym Archiwum Historycznym Białorusi w Mińsku udało się odnaleźć niewielki, zaledwie dwustronicowy fragment księgi grodu grodzieńskiego z $1667 \mathrm{r} .{ }^{10} \mathrm{Na}$ szczególną uwagę zasługują także wypisy $\mathrm{z}$ ksiąg grodzkich powiatu grodzieńskiego przenoszone do akt ziemskich tegoż powiatu. Zauważmy też, że dysponujemy pełnym kompletem 37 ksiąg akt ziemskich $\mathrm{z}$ lat $1587-1668^{11}$.

\section{Casus starosty grodzieńskiego Teodora Skumina Tyszkiewicza (1589-1618)}

Poznane źródła umożliwiają ukazanie kilku aspektów działalności sądu grodzkiego grodzieńskiego. Jednak zanim przejdziemy do ich analizy, warto odnieść

${ }^{5}$ Grodzieńskie Państwowe Muzeum Historyczno-Archeologiczne (dalej: GPMHA), nr 15112/8, s. 1v-2; А. Шаланда, Радавод і герб зямян Гарадзенскага павету Пуціўлянінаў Свяикіх у другой палове XVI-XVIII cm., „Герольд Litherland” 2001, nr 1, s. 19-20.

${ }^{6}$ Wypis stanowi uwierzytelnioną kopię dokumentu, poświadczoną przez urząd, wystawianą na prośbę petenta; zob. В. Поліщук, Офіційні свідкі в структурі Луцького замкового уряду до реформ 1564-1566 років (службове підпорядкування і правові послуги), Київ 2003, s. 8.

${ }^{7}$ NAHB w Mińsku, f. 1711, op. 1, nr 187, s. 1-9v (8 IV 1595, 5 VIII 1599, 5 II 1655, 7 VII 1659); f. 694, op. 4, nr 654/2, s. 140-141 (2 I 1590); f. 694, op. 4, nr 939, s. 125-125v (17 VI 1624); f. 694, op. 1, nr 1667, s. 84-84v (28 VII 1667); f. 694, op. 4, nr 1027, s. 79v-80 (29 VIII 1668).

${ }^{8}$ NAHB w Grodnie, f. 1664, op. 1, nr 439, s. 1-3v (5 XI 1591); f. 128, op. 1, nr 10, s. 2-3 (10 VIII 1618), 4-4v (7 I 1620); f. 128, op. 1, nr 3, s. 8-8v (15 V 1625); f. 128, op. 1, nr 9, s. 19 (18 IV 1638); f. 128, op. 1, nr 5, s. 10-16 (20 VII 1655); f. 1759, op. 1, nr 1, s. 1-2 (20 X 1664).

${ }^{9}$ GPMHA, nr 8237 (3 II 1595), 9216 (14 V 1599), 9216/50 (8 VII 1603), 8732/182 (5 IX 1605), 8243 (4 III 1611), 8244 (1611), 9216/34 (20 V 1611), 9216 (1 VI 1611), 8245 (8 VII 1614), 8246 (8 IV 1616), 8732/72 (2 II 1619), 9216 (5 VI 1620), 9216 (14 II 1623), 9216/41 (10 I 1624), 9216 (30 VII 1627), 9216/31 (26 VIII 1631), 8250 (8 I 1632), 8251 (13 III 1632), 9216 (8 I 1638), 9216/86 (26 VII 1643), 8253 (15 VIII 1646), 9216/143 (10 VI 1653), 9216 (20 VII 1653), 9216 (5 VI 1654).

${ }^{10}$ NAHB w Mińsku, f. 1711, op. 1, nr 214, s. 1-2v.

${ }^{11}$ NAHB w Mińsku, f. 1755, op. 1, nr 11-47. Analizy działalności na podstawie ksiąg ziemskich grodzieńskich z lat 1566-1601 dokonała L. Iwanowa; zob. Л. Іванова, Гарадзенскі земскі суд у канцы XVI ст. У кантэксие Статутаў Вялікага Княства Літоўскага 1566 і 1588 г2., „Arche. Пачатак” 2014, nr 11(132), s. 106-107. 
się do trzech znanych dokumentów króla polskiego i wielkiego księcia litewskiego Zygmunta III Wazy. Po pierwsze, na mocy przywileju z 28 stycznia 1588 r. zatwierdzono „poprawiony na nowo” III Statut Wielkiego Księstwa Litewskiego ${ }^{12}$. Zestawienie go z treścią II Statutu z $1566 \mathrm{r}$. pozwala zauważyć doprecyzowanie zakresu działalności sądów grodzkich, których dogłębnej analizy dokonał Iwan Łappo. Zgodnie z nowym statutem wprowadzono obowiązkową przysięgę starosty sądowego „ротою судьи земъского”. Zakazano pełnienia przez tę samą osobę dwóch urzędów dworskich, ziemskich, starościńskich sądowych. Stwierdzono przy tym, że urzędnikami grodu powinni być obywatele Wielkiego Księstwa Litewskiego osiedli $\mathrm{w}$ danym powiecie, dobrze obeznani $\mathrm{z}$ prawem i umiejący pisać „po rusku”. Regularne roczki sądów grodzkich winny odprawiać się co miesiąc i trwać dwa tygodnie. Księgi aktowe należało przechowywać w należytym porząadku. Rozszerzono również kompetencje sądów grodzkich. Szczegółowo omówiono tryb postępowania sądowego, uprawnienia urzędników oraz prawa stron procesowych, a także wysokość opłat sądowych ${ }^{13}$. Według III Statutu urzędnicy grodzcy zajmowali w hierarchii urzędów powiatowych miejsce po pisarzu sądu ziemskiego ${ }^{14}$.

Na mocy drugiego przywileju wystawionego tego samego dnia, czyli 28 stycznia 1588 r., starostwo grodzieńskie z dworami: Horodnica, Nowy Dwór, Łabno, Krynki, Odelsk, Kraśnik, Kwasówka, Kuźnica, Kotra, Skidel, Wiercieliszki, Jeziory, Sałaty, Milkowszczyzna i Mosty uzyskało status ekonomii królewskiej ${ }^{15}$, wpływy z niej miały zasilać skarb hospodarski. Dzierżawcami tych dóbr mieli być osiadli na Litwie „członkowie narodu litewskiego”. Ustanowiono, że Skidel, Wiercieliszki, Jeziory i Sałaty miała dzierżawić dożywotnie Anna Jagiellonka, wdowa po Stefanie Batorym. Po jej śmierci dwory te miały powrócić do dóbr stołowych starostwa grodzieńskiego ${ }^{16}$.

W ten sposób wraz z nadaniem przywileju Zygmunta III Wazy ostatecznie ukształtowała się grodzieńska ekonomia królewska, początkami sięgająca $1578 \mathrm{r}$. Dobrami ekonomicznymi zarządzał ekonom, tradycyjnie określany „sprawcą

12 Статут Вялікага Княства Літоўскага 1588. Тэксты. Даведнік. Каментарыі, red. І. Шамякін et al., Мінск 1989, s. 42-43; H. Lulewicz, Gniewów o unię ciagg dalszy. Stosunki polsko-litewskie w latach 1569-1588, Warszawa 2002, s. 414.

${ }^{13}$ И. Лаппо, Гродский суд в Великом княжестве Литовском в XVI столетии, „Журнал Министерства Народного Просвещения" n.s. 13, 1908, nr 1, dz. 2, s. 56-57, 58, 63-64, 68-69, 70, 81, 82-83, 91-94, 95-96, 101-103, 105-107, 109-110; zob. A.B. Zakrzewski, Wielkie Księstwo Litewskie (XVI-XVIII w.). Prawo - ustrój - społeczeństwo, Warszawa 2013, s. 183.

${ }^{14}$ Cтатут Вялікага Княства Літоўскага 1588..., s. 116; Urzędnicy Wielkiego Księstwa Litewskiego. Spisy. Województwo trockie XIV-XVIII wiek, t. 2, red. A. Rachuba, oprac. H. Lulewicz et al., Warszawa 2009, s. 22.

${ }^{15}$ Акты, относящиеся к истории Западной России (1588-1632), t. 4, Санкт-Петербург 1851, s. 1; H. Lulewicz, op. cit., s. 415.

${ }^{16}$ Aкты, относящиеся к истории Западной России..., t. 4, s. 2-3. 
dworów grodzieńskich Jego Królewskiej Mości”, dzierżawcą lub nawet starostą grodzieńskim. Wzmianka z marca 1588 r. wspomina starostę Stefana Bielawskiego, dysponującego w Grodnie własną administracją, tj. namiestnikiem zamkowym oraz podnamiestnikiem. Bielawski był także znany jako dzierżawca dworu w Jeziorach, Sałatach, Skidlu i Wiercieliszkach, należących do Anny Jagiellonki $(\dagger 1596)^{17}$.

Analiza przywileju z 1588 r., traktującego o dobrach stołowych, pozwala na lepsze zrozumienie przypadku podskarbiego ziemskiego i pisarza litewskiego Teodora Skumina Tyszkiewicza $(1586-1590)^{18}$, wzmiankowanego w źródłach jako starosta grodzieński. Nie sposób zgodzić się z badaczami negującymi użycie takiej tytulatury ${ }^{19}$ bądź mylącymi go z grodzieńskim starostą sądowym ${ }^{20} . \mathrm{Z}$ treści królewskiego przywileju wynika, że dobra stołowe w starostwie grodzieńskim z rąk Polaka Stefana Bielawskiego miał przejąć właśnie podskarbi ziemski litewski ${ }^{21}$ - Litwin Fiodor (dalej: Teodor) Skumin Tyszkiewicz. W jednym z przekazów, datowanym na 23 kwietnia 1589 r., został on nazwany starostą grodzieńskim ${ }^{22}$. Jak można się domyślać, jego urząd starościński miał związek z ekonomią grodzieńską, a objęcie tego stanowiska odbyło się nieco wcześniej. W panegiryku wydanym w Wilnie w 1618 r., po śmierci Teodora Skumina Tyszkiewicza, Monumentum virtuti meritissimae Perillustris et Magnifici Herois D[omini] Theodori Tiskiewicz Skumin Palatini Novogroden[sis], Grodnensis, Olyten[sis], Iurburgen[sis], Novowolensis Capitanei, również wspomina się, że był on „starostą ekonomii grodzieńskiej" już w czasie koronacji Zygmunta III ${ }^{23}$.

Mianowanie Teodora Skumina Tyszkiewicza na urząd ekonoma oznaczało rozdzielenie uprawnień sądowych pomiędzy niego a starostę grodzkiego

17 А. Шаланда, Гродскі суд Гарадзенскага павета ВКЛ у часы прайлення Стэфана Баторыя..., s. $56-58$.

${ }^{18}$ Urzędnicy centralni i dostojnicy Wielkiego Księstwa Litewskiego XIV-XVIII wieku. Spisy, oprac. H. Lulewicz, A. Rachuba, Kórnik 1994, s. 156.

${ }^{19}$ Urzędnicy Wielkiego Księstwa Litewskiego. Spisy. Województwo trockie..., s. 337.

${ }^{20}$ А. Грыцкевіч, Тышкевічы, w: Вялікае Княства Літоўскае. Энцыклапедыя, t. 2, wуd. 2, Мінск 2007, s. 681.

${ }^{21}$ Акты, относящиеся к истории Западной России..., t. 4, s. 1.

${ }^{22}$ Акты, издаваемые Виленской археографической комиссией, t. 2, Вильна 1867, s. 14. Stefan Bielawski jest wzmiankowany jako były starosta grodzieński i kowieński w przywileju Zygmunta III wystawionym dla podstarościego grodzieńskiego Węcława Wdanowskiego 7 IV 1590; zob. GPMHA, nr 9219/15, s. 1.

23 „Nam hic postquam felicissime in regnum sibi delatum ingressus fuiss et, eum Cracoviae humilem se suae Regiae Maiestatis subditum conceptis verbis profitentem, Capitaneum Oeconomumque Grodnensem esse voluit”; „Namque Sigismundo Regali in sede locato, Iurat ubi obsequium, Rex hunc complexus amanter; Praeses et Oeconomus, vir, ait, sis inclyte Grodnae", zob. Monumentum virtuti meritissimae Perillustris et Magnifici Herois D[omini] Theodori Tiskiewicz Skumin Palatini Novogroden[sis], Grodnensis, Olyten[sis], Iurburgen[sis], Novowolensis Capitanei..., Vilnae [1618], f. A2, D3v. 
grodzieńskiego Jana Wasiljewicza Klukowskiego. Kompetencje tego ostatniego nie rozciągały się na dobra starostwa należące do ekonomii ${ }^{24}$, lecz tylko na powiat grodzieński. Dla ekonomii grodzieńskiej reaktywowano bowiem sąd zamkowy - sprawowany przez Teodora Skumina Tyszkiewicza ${ }^{25}$. Siedziba tej instytucji, której nie należy mylić z sądem grodzkim, mieściła się zapewne na dolnym zamku grodzieńskim. Sąd tworzył starosta wraz z wyznaczonymi przez niego podstarościmi ${ }^{26}$, prowadzono też odrębne księgi zamkowe ${ }^{27}$. Jurysdykcji zamkowej podlegali poddani hospodarscy ekonomii grodzieńskiej: chłopi, mieszczanie oraz bojarzy. Wyższą instancją apelacyjną dla tego sądu był sąd wielkoksiążęcy ${ }^{28}$. $\mathrm{W}$ postępowaniu procesowym między administracją ekonomii i poddanymi monarchę reprezentowali rewizorowie ${ }^{29}$.

Trzecim analizowanym dokumentem jest przywilej wystawiony 1 lutego 1588 r. Warunek stanom WKsLit. na sejmie koronacyi uczyniony, na którego mocy wprowadzono III Statut litewski, a także dokonano reorganizacji pracy Głównego Trybunału Wielkiego Księstwa Litewskiego. Odtąd województwo trockie, a co za tym idzie i powiat grodzieński, miało sądzić się w Wilnie w ciągu 3 tygodni. Poza tym uznano decyzje sądów kapturowych z okresu ostatniego bezkrólewia:

Суды каптуровые и поступки до нихъ, которые по смерти короля его милости [Stefana Batorego - A.Š.], отъ становъ великого князства Литовского где-кольвекъ у великомъ князстве были постановлены [...] ствержаемъ и змоцняемъ: которыхъ и екзекуцыя подлугъ постановленья доходити и отправована быти маеть ${ }^{30}$.

Sformułowanie to ma bezpośredni związek z postanowieniami sądu kapturowego grodzieńskiego z lat 1587-1588, opartego na personelu sądu grodzkiego, któremu przewodniczył Jan Wasiljewicz Klukowski ${ }^{31}$. Formalnie bezkrólewie na

24 А. Шаланда, Гродскі суд Гарадзенскага павета ВКЛ у часы праўлення Стэфана Баторыц..., s. $81-82$.

${ }^{25}$ Nie znamy żadnych materiałów ukazujących działalność sądową poprzedniego ekonoma grodzieńskiego Stefana Bielawskiego.

${ }^{26}$ Swoim zarządem starosta Teodor Skumin Tyszkiewicz obejmował podstarościch miasteczek i folwarków „stołowych”; przykładowo: w 1592 r. podstarościm odelskim był Adam Wańkiewicz; zob.: NAHB w Grodnie, f. 1755, op. 1, nr 12, s. 176v.

${ }^{27}$ NAHB w Grodnie, f. 128, op. 1, nr 8, s. 2, 6.

28 А. Шаланда, Род Антонія дэ Кгрыпа, муляра замка Гарадзенскага ў канцы XVI - першай палове XVII cm., w: Castrum, urbs et bellum. 36. навук. праu, Баранавічы 2002, s. 406, 407; idem, Антоні дэ Кгрып - муляр гарадзенскага замка і яго род у каниы XVI - першай палове XVII cm., „Краязнаўчыя запіскі” 2012, nr 8, s. 18, 20.

${ }^{29}$ NAHB w Mińsku, KMF-18, Metryka WKL, nr 85, s. 86.

${ }^{30}$ Акты, относящиеся к истории Западной России..., t. 4, s. 4-5; H. Lulewicz, op. cit., s. 415-416.

${ }^{31}$ А. Шаланда, Гродскі суд Гарадзенскага павета ВКЛ у часы праўлення Стэфана Баторыя..., s. 80, 82; 3. Антановіч, Гарадзенскі каптуровы суд у XVII-XVIII cmcm., w: Гарадзенскі палімпсест III. 2010..., s. 76-77; Акты, издаваемые Виленской археографической комиссией, t. 1, Вильна 1865, s. 135. 
Litwie skończyło się 1 kwietnia 1588 r. Od tego czasu w imieniu nowego monarchy pracę wznowiły sądy powiatowe ${ }^{32}$.

\section{Sąd grodzki i III Statut litewski: problem kniazia Lwa Massalskiego}

Zgodnie z III Statutem sąd grodzki mógł obradować w dwóch składach: starosty i pisarza, a w przypadku nieobecności starosty: podstarościego, sędziego i pisarza grodzkich $^{33}$. Urzędnicy grodzcy grodzieńscy w dwóch swoich sądowych składach - starosta sądowy Jan Wasiljewicz Klukowski i pisarz Stefan Janowicz Nieszkowski lub podstarości Węcław Janowicz Wdanowski, sędzia Sołujan Bogufał Doroszkiewicz i pisarz Stefan Janowicz Nieszkowski - ostatni raz wspomniani są w dostępnych źródłach na początku grudnia $1588 \mathrm{r} .{ }^{34} \mathrm{~W}$ roku następnym sąd stał się swego rodzaju "przedsiębiorstwem rodzinnym” starosty grodzieńskiego Jana Klukowskiego, kumulującego stanowiska w rękach swoich i rodziny. Pierwszy opuścił urząd sędzia grodzki Sołujan Bogufał Doroszkiewicz ${ }^{35}$. W maju 1589 r. stanowisko to objął Bogdan Żdanowicz Słowik ${ }^{36}$, zięć Jana Klukowskiego ${ }^{37}$. Urząd podstarościego planowano powierzyć Marcinowi Stefanowiczowi Skorulskiemu, kolejnemu zięciowi Klukowskiego ${ }^{38}$, którego w liście z grudnia 1589 r. marszałek królewski, kniaź Fiodor Iwanowicz Massalski, nazwał swoim „przyjacielem”, „horodniczym i podstarościm grodzieńskim”39. Nawiasem mówiąc, 2 kwietnia 1588 r. zastąpił on na stanowisku horodniczego swego teścia ${ }^{40}$. Nepotyzm rzucał się więc w oczy. Zapewne z tego powodu Marcin Skorulski nie stawił się na urzędzie starościńskim, a Węcław Wdanowski przedłużył swoją kadencję do

${ }^{32}$ H. Lulewicz, op. cit., s. 416.

${ }_{33}$ Статут Вялікага Княства Літоўскага 1588..., s. 168-169, rozdz. 4, art. 37-38.

${ }^{34}$ NAHB w Mińsku, f. 1755, op. 1, nr 11, s. 268 v; Urzędnicy Wielkiego Księstwa Litewskiego. Spisy. Województwo trockie..., s. 315; А. Шаланда, Гродскі суд Гарадзенскага павета ВКЛ у часы праўлення Стэфана Баторыя..., s. 82.

${ }^{35}$ NAHB w Mińsku, f. 1755, op. 1, nr 11, s. 162v-164v. Testament Sołujana Bogufała Doroszkiewicza był napisany 10 VI 1588 i aktykowany w grodzie 8 sierpnia, po jego śmierci przeniesiony do ksiąg ziemskich grodzieńskich 16 I 1589.

${ }^{36}$ Urzędnicy Wielkiego Księstwa Litewskiego. Spisy. Województwo trockie..., s. 315.

37 Żoną Bogdana Żdanowicza Słowika była Barbara Janowna Klukowska; zob. NAHB w Mińsku, f. 1755, op. 1, nr 13, s. 120-120v, 391v, 392, 392v, 394.

38 Żoną Marcina Stefanowicza Skorulskiego była Hanna Janówna Klukowska; zob. ibidem, s. 393.

${ }^{39}$ Co prawda Marcin Skorulski podpisał się pod listem tylko jako horodniczy grodzieński: „Marcin Skorulsky horodniczy grodzienski własną ręką" (NAHB w Mińsku, f. 694, op. 4, nr 654-2, s. 141), ale w liście dzielczym Michała Sopoćki z dnia 2 XII 1588 wśród świadków i pieczętarzy podpisał się jako horodniczy i podstarości grodzieński (NAHB w Mińsku, f. 1755, op. 1, nr 11, s. 270v).

${ }^{40}$ Urzędnicy Wielkiego Księstwa Litewskiego. Spisy. Województwo trockie..., s. 252. 
końca $1591 \mathrm{r}^{41}{ }^{4}$ Również doświadczony Stefan Nieszkowski nadal pełnił urząd pisarski $^{42}$.

W 1590 r. podstarości Węcław Wdanowski, sędzia Bogdan Słowik i pisarz Stefan Nieszkowski zasiadali na roczkach sądowych grodzkich „на местцу судовомъ звыклом" ${ }^{43}$. Starosta Jan Klukowski, przewodniczący czerwcowych roczków z 1595 r., stwierdził że jest „на местъцу судовомъ в замку в Городъне”44. Być może w tym samym budynku odbywały się również posiedzenia sądu ziemskiego grodzieńskiego ${ }^{45}$. Na zamku tradycyjnie znajdowało się również „везене кгродъское" 46 .

Dobrą ilustracją rozprawy sądowej odbywającej się w grodzie grodzieńskim jest dekret Jana Klukowskiego w sprawie kniazia Lwa Iwanowicza Massalskiego, który 5 listopada 1591 r. na roczkach „з позву кгродского” wytoczył proces Krzysztofowi Mikołajewiczowi Monwidowi Dorohostajskiemu, krajczemu litewskiemu, staroście wołkowyskiemu i dzierżawcy szereszowskiemu, autorowi znanej Hippiki.

Z treści skargi wynikało, że 2 listopada 1590 r. „неведати дей для чого” Hryhory Maciejewicz Gornieński Bezpiaty, namiestnik wołkowyski Dorohostajskiego, ze służbą i poddanymi hospodarskimi starostwa wołkowyskiego najechali majątek wołczkowski, należący do księcia, położony nad rzeką Rosią w powiecie wołkowyskim, niszcząc młyn:

который дей он собе збудовал немалым коштом на реце Роси на властном кгрунте своем лежачом под селом его ж м[и]л[о]сти называемым Ятвезю4 ${ }^{47}$

Wysokość szkód spowodowanych tym zajazdem oszacowano na kwotę 200 kop groszy litewskich. Na dodatek doszło wówczas do pobicia i zranienia urzędnika Massalskiego - Jerzego Szymkowicza. Przeciwdziałanie urzędników grodzkich starosty wołkowyskiego Krzysztofa Dorohostajskiego zmusiło pokrzywdzonego do zwrócenia się do sądu:

дей писар его м[и]л[о]сти кгродский волковыский пан Станислав Петрашевский обжалованя его [Lwa Massalskiego - A.Š.] не прынял и до книг записати не хотел, што дей он там же в месте его королевское м[и]л[о]сти Волковыском на враде месцъком оповедал, так же и тут на враде моем [Jana Klukowskiego - A.Š.] кгродском Городеньском, водле

\footnotetext{
${ }^{41}$ Ibidem, s. 306.

${ }^{42}$ NAHB w Mińsku, f. 694, op. 4, nr 654-2, s. 141; Urzędnicy Wielkiego Księstwa Litewskiego. Spisy. Województwo trockie..., s. 282-283.

${ }^{43}$ Акты, издаваемые Виленской археографической комиссией, t. 31, Вильна 1906, s. 73-74, 77, $80,84-85,86-87$.

${ }^{44}$ Ibidem, s. 243.

${ }^{45}$ Volumina Constitutionum, t. 2, cz. 2, wyd. S. Grodziski, Warszawa 2008, s. 155.

${ }^{46}$ Акты, издаваемые Виленской археограбической комиссией..., t. 31, s. 202-203; zob. też: „на замку Городенскомъ на дне у веже”, „в замку Городенскомъ въ вежы на дне”, ibidem, t. 1, s. 269 (16 I 1615), 316 (16 I 1646).

${ }^{47}$ NAHB w Grodnie, f. 1664, op. 1, nr 439, s. 1.
} 
права посполитого, зараз ожаловал и возному его королевское м[и]л[о]сти енералу повету Городеньского Лукашу Ейсимонту и Станиславу Тупику, возному повету Волковыского оный кгвалт и шкоды оказал ${ }^{48}$.

Obecny był w sądzie Łukasz Eysymont - pierwszy woźny generał powiatu grodzieńskiego, wprowadzony na ten urząd zgodnie z III Statutem ${ }^{49}$, nominowany zaś 16 kwietnia 1590 r. ${ }^{50}$ Wiadomo, że Eysymont „пры стороне шляхъте" wyruszył na miejsce zatargu w powiecie wołkowyskim, przeprowadzając wizję i stwierdzając dokonanie szkód młyna Lwa Massalskiego oraz pobicia jego urzędnika Jerzego Szymkowicza:

на котором видел на плечы руки правое рану битую синюю опухълую51.

W listopadzie $1591 \mathrm{r}$. posiedzenia grodzkich roczków sądowych w Grodnie odbyły się nie na początku miesiąca, ponieważ na pierwszy dzień - był to piątek - przypadło święto Wszystkich Świętych „водле календару рымского”:

на который день иж врад кгродский на справах судовых не заседал ${ }^{52}$.

$\mathrm{Z}$ tego też względu sąd grodzki nie zebrał się w niedzielę:

тогды почавшы за першый ден[ь] того м[еся]ца ноябра второго у суботу и на другом дни у понеделок так и вовторок через вси тры дни у суду становилъся [Lew Massalski - A.Š.] и на кождый день пильност[ь] чынечы стороны своей позваное его м[ило]сти п[а]на крайчого через возного ку усправедливеню врадовне прыволыват[ь] давал ${ }^{53}$.

Po trzech „wołaniach”, na trzeci dzień toczącej się rozprawy - 5 listopada jako pełnomocnik pozwanego Krzysztofa Dorohostajskiego stawił się szlachcic powiatu grodzieńskiego Adam Eysymont, „менечыся быть умоцованым од его м[и]л[о]ст[и] п[а]на своего" 54 . Jako dowód okazał list „umocowany” z 29 października $1591 \mathrm{r}$. z przystawioną pieczęcią i podpisem krajczego litewskiego, starosty wołkowyskiego, kwestionując prawidłowość doręczenia pozwu sądowego, gdyż woźny grodzieński Stefan Radziwanowski

фал[ь]шыве подане того позву на рочки теперешние на враде здешънем сознал не положывшы ихъ у дворе короля его м[и]л[о]сти волковыском ${ }^{55}$.

\footnotetext{
${ }^{48}$ Ibidem, s. 1-1v.

${ }^{49}$ Статут Вялікага Княства Літоускага 1588..., s. 212-213, rozdz. 4, art. 104.

${ }^{50}$ Л. Іванова, op. cit., s. 114-115.

${ }^{51}$ NAHB w Grodnie, f. 1664, op. 1, nr 439, s. 2v.

${ }^{52}$ Ibidem, s. 1v.

${ }^{53}$ Ibidem.

${ }^{54}$ Ibidem.

${ }^{55}$ Ibidem.
} 
Mimo to, po zapoznaniu się z treścią pełnomocnictwa Adama Eysymonta, kniaź Lew Massalski zwątpił w jego moc prawną:

менечы быть, што дей только паном сенатором то право належыт таковые листы умацаваныя до врадов за одною своею печатью за подписом руки своей давати, а его м[и]л[ос]ть панъ крайчый, хотяж есть зацным врадником его королевское м[и]л[о]сти столовым и старостою, до того сенаторскимъ сыном, ведъже еще сам не есть сенатором, для чого, яко инный шляхътич пры печати его м[и]л[о]сти мела бы быть другая печать шляхетская прыложона ${ }^{56}$.

Ponadto powołał się na art. 56 z rozdz. 4 III Statutu, prosząc sąd grodzki o unieważnienie pełnomocnictwa Adama Eysymonta oraz odsunięcie go od udziału w rozprawie. Zauważmy, że Statut zawierał następną normę:

Панове рады, даючы такие листы умоцованые тол[ь]ко под печатью своею и с подписом руки своее властное, а иншые станы такеж, даючи листы под печатью и с подписом руки своее и при своей печати, еще под одною печатью чоловека сторонного ${ }^{57}$.

Zapewne kniaź Lew Massalski posiadał jakiś egzemplarz Statutu, nieźle więc znał obowiązujące prawo. Wszystkie bowiem jego odwołania się do kodeksu można uznać za trafne. Zresztą, w wyniku zbadania pieczęci, sąd grodzki musiał się zgodzić z jego argumentami, przyznając mu rację:

в чом врад водле того артыкулу оную прымову его за слушъную быть узнавшы и оного умоцованого на сторону одставил ${ }^{58}$.

W tej sytuacji, uświadamiając sobie niesprzyjający przebieg rozprawy, Adam Eysymont poprosił „о годину на обмову альбо на пораду собе в той справе”, składając obietnicę dostarczenia innej „mocy”. Pomimo protestów strony pozywającej, starosta Jan Klukowski wyraził zgodę, wymagając przy tym spełnienia warunku:

чого ему врад над право посполитое позволил, кгдыж будучы одставленый на другой моцы, вжо поправоватися не мел ${ }^{59}$.

Tymczasem Adam Eysymont nie zdążył na czas dotrzymać słowa:

иж за годину од враду ему узычоную до суду зыншою моцю не прыбыл, а в том часе нешпорная година вышла, а яко возъный Богдан Нарбутович сознал, што вже в тот час и по нешъпоре было ${ }^{60}$.

\footnotetext{
${ }^{56}$ Ibidem.

${ }^{57}$ Статут Вялікага Княства Літоўскага 1588..., s. 212-213, rozdz. 4, art. 56.

${ }^{58}$ NAHB w Grodnie, f. 1664, op. 1, nr 439, s. 1v.

${ }^{59}$ Ibidem, s. 2.

${ }^{60}$ Ibidem.
} 
Co prawda nieco później „по нешъпоре” Adam Eysymont dostarczył niezbędny dokument $\mathrm{z}$ dwiema pieczęciami, ale - niestety - już po wyroku zapadłym na korzyść kniazia Lwa Massalskiego. Podstawą tego orzeczenia był brak zgodnego z prawem listu Krzysztofa Dorohostajskiego, co w obliczu sądu czyniło go „nieposłusznym” wobec norm Statutu:

прото, яко на третемъ дни на року завитом за непрыбытемъ умоцованого его м[ило]сти п[а]на крайчого за несталого и з верхности враду короля его м[и]л[о]сти за позвы кгродскими за непослушного од враду узънано есть ${ }^{61}$.

Nie doczekawszy się przedstawienia $\mathrm{w}$ terminie niezbędnych dowodów, kniaź Lew Massalski wygrał rozprawę z krajczym litewskim i starostą wołkowyskim. Po pierwsze, odparł zarzuty obżałowanego, udowodniając autentyczność pozwu:

довел написом на том позве власною руко[ю] писаня и устъным прызнанемъ на враде здешънемъ возного поветового Стефана Радивоновского, который оные позвы в року теперешънем тисеча пятсот деветьдесят первомъ м[еся]ца октебра третего дня пры стороне двох шляхътичох у дворе его королевское м[и]л[о]сти волковыскомъ у ворота дворные увоткнул и челеди дворной оказал ${ }^{62}$.

Po drugie, okazał aż sześć pozwów grodzkich ze świadectwami woźnego o wręczeniu wezwania do sądu, dowodząc tym samym właściwości jurysdykcji grodzkiej w jego sprawie:

того, ижъ тая справа зъ кгроду до земъства [sądu ziemskiego - A.Š.] не вышъла и тепер за сими позвы властне кгродскому суду тую справу належыть судити ${ }^{63}$.

Po trzecie, pomimo odrzucenia pierwszego pozwu na styczniowych roczkach 1591 r. przez Krzysztofa Dorohostajskiego „листом своим большостю з справ пры дворе короля его м[и]л[о]сти [будучого]"64, zbiciem przez niego sług umocowanych podczas następnych sesji innych pozwów z udowodnieniem swoich racji „прычынами въ Статуте описаными”, a jeszcze po dwóch pozwach „рочки ку одсуживаню не дошли за незаседанемъ враду кгродского”, kniaź

${ }^{61}$ Ibidem.
${ }^{62}$ Ibidem.
${ }^{63}$ Ibidem.

${ }^{64}$ Zdaniem Uładzimira Padalińskiego Krzysztof Dorohostajski nie brał udziału w posiedzeniach sejmowych w grudniu 1590 i styczniu 1591 r.; zob. У. Падалінскі, Крыштоф Дарагастайскі пасол на соймы Рэчы Паспалітай (1587-1596 гг.), w: Ашмяншчына. Праблемы рэгіянальнай zісторыі Беларусі: зб. навук. арт., red. А. Каваленя et al., Мінск 2011, s. 136-149. Niewykluczone jednak, że uczestniczył w pracach sejmowych, posiadając inny status, np. mógł wykonywać jakieś królewskie zadania. Dlatego też nie był w stanie pojawiać się w sądzie grodzkim grodzieńskim w tym czasie. 
Lew Massalski na mocy dostarczonych dokumentów dowiódł stałego pozywania swojego przeciwnika do sądu:

которыми он часу выбитя спокойного держаня невыпускаючы зъ десети недел[ь] его м[и]л[о]сти п[а]на крайчого до суду здешънего позывал ${ }^{65}$.

Oprócz pozwów kniazia Lwa Massalskiego do sądu dostarczono wypis z ksiąg grodzkich „враду здешънего” z 4 listopada 1590 r. ze skargą, opisem szkód i śladów pobicia urzędnika Massalskiego w majątku wołczkowskim, wykonany przez generała grodzieńskiego Łukasza Eysymonta, a także wypis z ksiąg magistratu wołkowyskiego z 3 listopada 1590 r. „под печатю местъскою с подъписом руки писара тамошнего Станислава Ивановича" о podobnej treści, poświadczony przez woźnego wołkowyskiego Stanisława Tupika ${ }^{66}$. Na podstawie tych dokumentach oraz powołując się na art. 27, 30 i 42 z rozdz. 4 III Statutu:

домовялся кн[я]зь Масал[ь]ский абы водле тых артыкулов згожаючыся з артыкулом деветьдесят вторым в том же четьвертомъ розделе описаным до держаня оного млына, с которого был выбит, знову урадовне был упущон такъ на всказъ враднику его, яко и шкоды за совитостью абы сказаны были ${ }^{67}$.

Ze względu na wzorowe przygotowanie kniazia Lwa Massalskiego do rozprawy staroście sądowemu grodzieńskiemu Janowi Klukowskiemu nie pozostawało nic innego jak uznać słuszność jego argumentów:

заховуючися водле права посполитого и тыхъ артыкулов из Статуту от стороны жалобное поданых, а меновите артыкул трыдцатый и сорок вторый, двадцать семый в розделе четьвертом, водле которых, кром дальшыхъ доводов невидечы быть потребы ихъ над тые арьтыкулы показовать, всказал и прысудил есьми, прыхиляючыся до артыкулов деветьдесят второго с того ж розделу четьвертого, в тот млын, с которого был кн[я]зь Лев Масальский одъ его м[и]л[о]сти п[а]на крайчого выбитъ, знову его м[и]л[ос]ть князя Масальского до держаня и ужываня оного млына врадовне упустить, прытом за кгвалт двадцать копъ грошей, а за бой навезъку тому враднику его м[и]л[о]сти Юрю Шымковичу, водле стану его, яко простого чоловека, две копе грошей, к тому за спустошене того млына, водле жалобы в позве описанное, за шкоды двесте копъ грошей, а совитости тым шкодам другую двесте копъ грошей, того всего презыску на его м[и]л[о]сти п[а]ну крайчомъ кн[я]зю Льву Масальскому въсказаного чынитъ чотырыста двадцать две копе грошей литовскихъ ${ }^{68}$.

Na wypadek niewpłacenia przez Krzysztofa Dorohostajskiego nałożonej na niego grzywny w terminie, wyrok sądu przewidywał zastosowanie następującego środka:

\footnotetext{
${ }^{65}$ NAHB w Grodnie, f. 1664, op. 1, nr 439, s. 2.

${ }^{66}$ Ibidem, s. $2 \mathrm{v}$.

${ }^{67}$ Ibidem, s. 3.

${ }^{68}$ Ibidem.
} 
которая сума за незаплаченемъ от его м[и]л[о]сти п[а]на крайчого его м[и]л[о]сти кн[я]зю Масал[ь]скому от поданя копеи з листу моего увящого за чотыры недели, яко презыскъ заочне на его м[и]л[о]сти всказаный, тогды на маетности его м[и]л[о]сти п[а]на крайчого властном, ал[ь]бо на суме п[е]н[е]зей, которую его м[и]л[о]сть на добрах короля его м[и]л[о]сти во враде староства своего маетъ, поступъком правным отправа скуточная вчынена быть маетъ 69.

Oczywiste jest, że III Statut od momentu wejścia w życie stał się głównym źródłem prawa dla systemu sądowego Litwy. Szczegółowe tłumaczenia różnorodnych problemów prawnych, w tym takich drobnych jak badanie pieczęci pełnomocnictw, nie dawało szansy stronie słabo przygotowanej w postępowaniu procesowym, w którym urzędnicy grodzcy mieli odgrywać rolę bezstronnych i obiektywnych arbitrów. Nie ulega wątpliwości, że w praktyce na ich decyzje wpływali również możni patroni. Interesujące jest to, że starosta grodzieński Jan Klukowski, który wydał niekorzystny wyrok w sprawie „senatorskiego syna”, zauważył, iż nie podejmował decyzji w pełni samodzielnie:

а так я, Ян Клюковский, староста городеньский, намовившыся з немало людей особъ зацных на той справе будучыми ${ }^{70}$.

Niestety, nie wiadomo, kto „doradzał” staroście grodzieńskiemu. Niemniej jednak obecność w sądzie grodzkim - poza starostą, podstarościm, sędzią, pisarzem oraz stronami i ich pełnomocnikami - innych „zacnych osób” miała dawną tradycję $e^{71}$. Podczas rozpraw sądowych dysponowały one głosem doradczym. Warto podkreślić, że pomimo niewątpliwej presji, związanej z wysokim statusem krajczego litewskiego Krzysztofa Dorohostajskiego, gród wydał wyrok zgodnie $\mathrm{z}$ prawem.

Przedstawiony powyżej przykład ukazuje nieregularne odbywanie sesji sądu grodzkiego grodzieńskiego. Pomimo obowiązującego wymogu roczki grodzieńskie nie zbierały się comiesięcznie, a to opóźniało toczące się w grodzie rozprawy. Należy zauważyć, że opisany stan rzeczy znajdował uzasadnienie w udziale urzędników sądu grodzkiego w pracach Głównego Trybunału Litewskiego:

рочки ку одсужываню не дошли за незаседанемъ враду кгродского будучы на тот час в справахъ своихъ у Трыбуналу виленьского, зачымъ до сего часу тая справа ку розсудку правному прыйти не могла ${ }^{72}$.

Można przypuszczać, że mogło tu chodzić o jakieś ich własne rozprawy sądowe. Nie posiadamy żadnych danych na temat udziału urzędników grodu

\footnotetext{
${ }^{69}$ Ibidem.

${ }^{70}$ Ibidem.

${ }^{71}$ А. Шаланда, Замкавы суд у Гарадзенскім павеще (другая палова XV-1566 г.), s. 20; idem, Гродскі суд Гарадзенскага павета ВКЛ у другой палове XVI-XVII стст. Частка I..., s. 28.

${ }^{72}$ NAHB w Grodnie, f. 1664, op. 1, nr 439, s. 2.
} 
grodzieńskiego $\mathrm{w}$ pracach Trybunału, nie można więc wykluczyć, że w latach 1590-1591 mogli oni brać udział w jego pracach ${ }^{73}$. Wobec nieobecności w mieście starosty lub innych urzędników posiedzenia sądu grodzkiego grodzieńskiego przenoszono więc na następne roczki ${ }^{74}$.

Zasłużony na tym urzędzie starosta sądowy grodzieński Jan Klukowski - sprawujący go przez 20 lat - zmarł po 27 października $1601 \mathrm{r} .{ }^{75} \mathrm{Ze}$ starego, wywodzącego się jeszcze z czasów przedwazowskich składu grodu pozostał jedynie jeden urzędnik - sędzia grodzki Stefan Nieszkowski, który w 1609 r. osiągnął szczyt swojej kariery - urząd pisarza grodzieńskiego sądu ziemskiego ${ }^{76}$.

\section{Drogi awansu urzędników grodu grodzieńskiego w latach 1587-1668}

W zbadanych źródłach udało się ustalić dane dotyczące 7 starostów sądowych oraz 30 urzędników grodu z okresu panowania Wazów, co przedstawiono w zamieszczonej poniżej tabeli ${ }^{77}$.

Nominacji nowego starosty grodzieńskiego towarzyszyło znaczące odnowienie składu grodzkiego urzędu, o czym świadczy stosowanie standardowej formuły „от вел[ь]можного п[а]на его м[и]л[о]сти [...] старосты городенского [...] на справы судовые высажоные"78. Nazwisko starosty nie pozostawia żadnej

${ }^{73}$ Deputaci Trybunału Głównego Wielkiego Księstwa Litewskiego (1582-1696). Spis, red. A. Rachuba, oprac. H. Lulewicz, A. Rachuba, Warszawa 2007, s. 80, 83.

${ }^{74}$ Podobne problemy z regularnymi sesjami sądów i urzędów grodzkich widać w Koronie; por:: J. Łosowski, Kancelaria grodzka chetmska od XV do XVIII wieku. Studium o urzędzie, dokumentacji, jej formach i roli w życiu społeczeństwa staropolskiego, Lublin 2004, s. 83-84; A. Moniuszko, Mazowieckie sądy ziemskie (1588-1648). Organizacja - funkcjonowanie - postępowanie, Warszawa 2013, s. 29-30.

${ }^{75}$ GPMHA, nr 9216, s. 1; Urzędnicy Wielkiego Księstwa Litewskiego. Spisy. Województwo trockie..., s. $337-338$.

${ }^{76}$ Urzędnicy Wielkiego Księstwa Litewskiego. Spisy. Województwo trockie..., s. 286, 315.

77 Oprac. na podst.: ibidem, s. 283-284, 306-307, 315-317, 337-338; NAHB w Mińsku, f. 1755, op. 1, nr 16, s. 830v (2 IV 1601); GPMHA, nr 9216/50, s. 1 (8 VII 1603), nr 9216, s. 1 (10 I 1606), nr 8243, s. 1 (4 III 1611), nr 9216/44, s. 1 (5 VIII 1621); NAHB w Mińsku, f. 1755, op. 1, nr 33, s. 110v (7 III 1625); f. 1755, op. 1, nr 34, s. 482 (18 IV 1631); GPMHA, nr 9216/31, s. 1 (26 VIII 1631); NAHB w Mińsku, f. 1755, op. 1, nr 35, s. 294v (5 IV 1634); f. 1755, op. 1, nr 36, s. 123v (6 III 1636); NHAB w Grodnie, f. 128, op. 1, nr 9, s. 13 (12 VII 1636), 14 (12 IX 1636); NAHB w Mińsku, f. 1755, op. 1, nr 37, s. 453 (5 III 1640); f. 1755, op. 1, nr 38, s. 334 (27 V 1644); GPMHA, nr 8253, s. 1 (15 VIII 1646); NAHB w Mińsku, f. 1755, op. 1, nr 40, s. 318 (9 V 1647), 496 (7 X 1647); f. 1755, op. 1, nr 42, s. 304-304v, 305v (5 II 1648); f. 1755, op. 1, nr 43, s. 523-523v (6 II 1654), 563v (5 III 1655); f. 1755, op. 1, nr 44, s. 229, 231 (5 IV 1658); f. 1755, op. 1, nr 46, s. 613-613v (7 X 1646); f. 694, op. 4, nr 1667, s. 84v (28 VII 1667); f. 694, op. 4, nr 1027, s. 79v, 80 (29 VII 1668). Boldem wyróżniono urzędników przenoszących się z jednego stanowiska na drugie w ramach sądu grodzkiego.

${ }^{78}$ NAHB w Mińsku, f. 1755, op. 1, nr 33, s. 110v; f. 1755, op. 1, nr 34, s. 482; f. 1755, op. 1, nr 35, s. 294v;

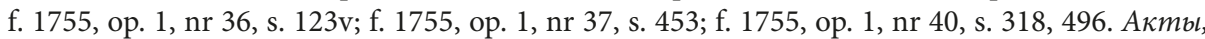


wątpliwości, kto był patronem tego lub innego urzędnika. Nie oznacza to, że nie zdarzały się wyjątki. Na przykład Jan Sopoćko niezmiennie pełnił urząd sędziego w latach $1623-1630$ i $1634-1636^{79}$ oraz podstarościego w latach 1636-1646, a więc w czasie urzędowania trzech starostów (Pawła Wołłowicza, Kazimierza Leona i Fryderyka Sapiehów). Kolejnym dowodem jest 27-letnie sprawowanie urzędu pisarza przez Mikołaja Michała Eysymonta w czasie pełnienia urzędu starosty przez obu Sapiehów.

Skład sądu grodzkiego grodzieńskiego w latach 1587-1668

\begin{tabular}{|c|c|c|c|}
\hline Starosta & Podstarości & Sędziowie & Pisarze \\
\hline $\begin{array}{l}\text { Jan Klukowski } \\
(1582-1601)\end{array}$ & $\begin{array}{l}\text { Węcław Wdanowski } \\
(1581-1591) \\
\text { Mikołaj Gnojnicki } \\
(1592-1598) \\
\\
\text { Jan Snarski } \\
(1598-1601)\end{array}$ & $\begin{array}{l}\text { Sołujan } \\
\text { Bogufał Doroszkiewicz } \\
(1579-1588) \\
\text { Bogdan Słowik } \\
(1589-1594) \\
\text { Jan Snarski } \\
(1595-1598) \\
\text { Stefan Nieszkowski } \\
(1598-1609)\end{array}$ & $\begin{array}{l}\text { Stefan Nieszkowski } \\
(1582-1598) \\
\text { Andrzej Czyż } \\
(1598-1601)\end{array}$ \\
\hline $\begin{array}{l}\text { Andrzej Wojna } \\
(1602-1615)\end{array}$ & 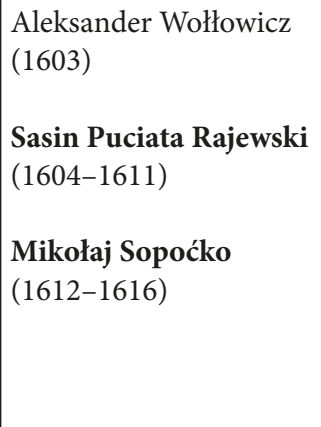 & 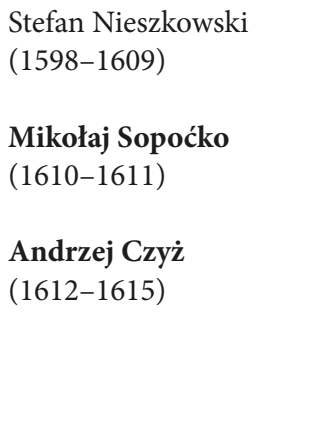 & 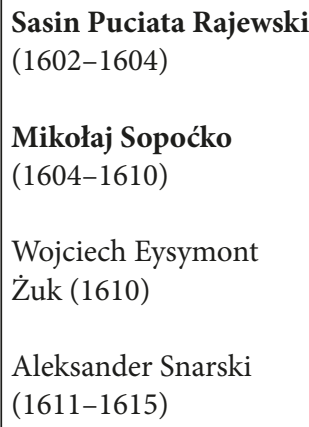 \\
\hline $\begin{array}{l}\text { Paweł Wołłowicz } \\
(1615-1630)\end{array}$ & $\begin{array}{l}\text { Mikołaj Sopoćko } \\
(1612-1616) \\
\text { Jan Campo } \\
(1617-1623)\end{array}$ & $\begin{array}{l}\text { Krzysztof Tołłoczko } \\
(1617-1623) \\
\text { Jan Sopoćko } \\
(1623-1630)\end{array}$ & $\begin{array}{l}\text { Fiłon Kozlowicki } \\
(1616-1621) \\
\text { Aleksander Snarski } \\
(1623-1629)\end{array}$ \\
\hline
\end{tabular}

издаваемье Виленской археографической комиссией.., t. 1, s. 163-164; В. Галубовіч, Справа пра напад на гарадзенскі кляштар францысканцаў у 1645 г., w: Гарадзенскі палімпсест II. 2009..., s. 255; Н. Сліж, Гарадзенскія падворкі XVII cm., w: Гарадзенскі палімпсест III. 2010..., s. 231.

${ }^{79} \mathrm{~W}$ wykazach urzędników powiatu grodzieńskiego z lat 1634-1636 brak wiadomości o sędzim grodzkim Janie Sopoćce; zob. Urzędnicy Wielkiego Księstwa Litewskiego. Spisy. Województwo trockie..., s. 316. 


\begin{tabular}{|c|c|c|c|}
\hline & 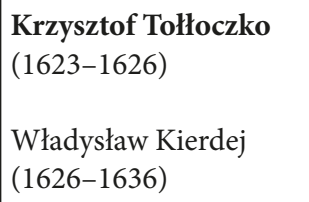 & & \\
\hline $\begin{array}{l}\text { Krzysztof } \\
\text { Chodkiewicz } \\
(1630-1633)\end{array}$ & $\begin{array}{l}\text { Władysław Kierdej } \\
(1626-1636)\end{array}$ & $\begin{array}{l}\text { Jan Odoliński } \\
(1631-1633)\end{array}$ & $\begin{array}{l}\text { Andrzej Jan Eysymont } \\
(1631-1633)\end{array}$ \\
\hline $\begin{array}{l}\text { Kazimierz Leon } \\
\text { Sapieha } \\
(1633-1636)\end{array}$ & $\begin{array}{l}\text { Władysław Kierdej } \\
(1626-1636) \\
\text { Jan Sopoćko } \\
(1636-1646)\end{array}$ & $\begin{array}{l}\text { Jan Sopoćko } \\
(1634-1636) \\
\text { Trojan Nabr Sułowski } \\
(1636-1637)\end{array}$ & $\begin{array}{l}\text { Mikołaj Michał } \\
\text { Eysymont } \\
(1633-1650)\end{array}$ \\
\hline $\begin{array}{l}\text { Fryderyk Sapieha } \\
(1636-1650)\end{array}$ & $\begin{array}{l}\text { Jan Sopoćko } \\
(1636-1646) \\
\text { Adam Kołycz } \\
(1646-1650)\end{array}$ & $\begin{array}{l}\text { Stanisław Wierzbowski } \\
(1637-1640) \\
\text { Adam Kołycz } \\
(1642-1646) \\
\text { Andrzej Poczobut Odla- } \\
\text { nicki (1646-1650) }\end{array}$ & $\begin{array}{l}\text { Mikołaj Michał } \\
\text { Eysymont } \\
(1633-1650)\end{array}$ \\
\hline $\begin{array}{l}\text { Andrzej Fran- } \\
\text { ciszek Kotowicz } \\
(1652-1676)\end{array}$ & $\begin{array}{l}\text { Paweł Kotowicz } \\
(1652-1659) \\
\text { Piotr Chreptowicz } \\
(1659-1663) \\
\text { Jerzy Olbrycht Micuta } \\
(1664-1670)\end{array}$ & $\begin{array}{l}\text { Andrzej Nowicki } \\
(1652-1659) \\
\text { Stefan Wawrzyniec } \\
\text { Rukiewicz (1661-1674) }\end{array}$ & $\begin{array}{l}\text { Piotr Chreptowicz } \\
(1652-1659) \\
\text { Jerzy Olbrycht Micuta } \\
\text { (1659-1664) } \\
\text { Aleksader Stanisław } \\
\text { Sopoćka (1664-1682) }\end{array}$ \\
\hline
\end{tabular}

Za nie mniej interesujące warto uznać kariery innych urzędników grodu: Sasina Puciaty Rajewskiego, Piotra Chreptowicza, Jerzego Olbrychta Micuty - awansujących ze stanowiska pisarza od razu na urząd podstarościego (!), Krzysztofa Tołłoczki, Jana Sopoćki, Adama Kołycza - z sędziów na podstarościch, Andrzeja Czyża - z pisarza na sędziego. Mikołaj Sopoćko przeszedł wszystkie trzy szczeble hierarchii służbowej grodu - pisarza, sędziego i podstarościego. Niektórzy, np. Stefan Nieszkowski, zakończyli karierę w sądzie ziemskim. W 1626 r. podstarości Krzysztof Tołłoczko uzyskał nominację na urząd podsędka ziemskiego grodzieńskiego. Jan Sopoćko w $1646 \mathrm{r}$. był mianowany podsędkiem ziemskim, a następnie sędzią (1648), Piotr Chreptowicz - pisarzem sądu ziemskiego (1663) oraz podsędkiem (1670), Andrzej Poczobut Odlanicki zaś pisarzem ziemskim oszmiańskim $(1650)^{80}$. Znane są przykłady szybkiego awansu na dygnitarstwa

${ }^{80} \mathrm{Ibidem}$, s. 287, 302-303, 307, 316, 322. 
centralne. W 1633 r. sędzia grodzki Jan Doliński, popierany przez Chodkiewiczów, objął urząd podkoniuszego litewskiego ${ }^{81}$. Opisana rotacja zawodowa w ramach struktury sądu grodzkiego grodzieńskiego dowodzi dużej stabilności tej instytucji oraz wzrostu prestiżu urzędów grodzkich ${ }^{82}$.

Analiza obowiązków służbowych ${ }^{83}$, bliskich stosunków koleżeńskich oraz stopnia powinowactwa ${ }^{84}$ pozwala zaryzykować twierdzenie o funkcjonowaniu w powiecie grodzieńskim specyficznej zawodowej korporacji, stanowiącej część politycznych elit lokalnych ${ }^{85}$. Starosta grodzieński oraz urzędnicy grodzcy uczestniczyli w pracach miejscowego sejmiku, a ich podpisy i pieczęcie widnieją pod uchwalonymi dokumentami ${ }^{86}$. Dobrą ilustrację tej tezy stanowi kolejny przykład: 2 lutego 1644 r. na sejmiku deputackim gromnicznym w Grodnie szlachta ze względu na swoje pilne potrzeby wybrała na urząd woźnego powiatu grodzieńskiego Andrzeja Steckiewicza. Zaświadczenie z prośbą skierowaną do wojewody trockiego Aleksandra Słuszki o „ustanowienie i postrzyżenie” go na woźnego podpisał starosta grodzieński Fryderyk Sapieha (jako trzeci, po kasztelanie trockim Stanisławie Sapieże i kasztelanie witebskim Ostafim Kurczu), dalej podstoli wołkowyski i grodzieński, sędzia grodzki Adam Kołycz, pisarz Mikołaj Eysymont oraz - bez podania stanowiska - podstarości Jan Sopoćko ${ }^{87}$. Jak można dopuszczać, roczki zawieszano w trakcie sejmików.

${ }^{81}$ Ibidem, s. 316; Urzędnicy centralni i dostojnicy Wielkiego Księstwa Litewskiego..., s. 153.

${ }^{82}$ Chodzi o pewien model kariery szlachcica oparty na jego fachowych umiejętnościach, zdobytych w grodzie; zob.: A. Moniuszko, Mazowieckie sądy ziemskie..., s. 161-163; idem, Sędziowie sądów szlacheckich w województwie płockim 1576-1600. Próba rekonesansu badawczego, „Studia z Dziejów Państwa i Prawa Polskiego" 19, 2016, s. 53-56.

${ }^{83} \mathrm{~W}$ lipcu 1628 i październiku 1629 r. podczas roczków ziemskich grodzieńskich podsędka ziemskiego Krzysztofa Tołłoczkę zastępował sędzia grodzki Jan Sopoćko; zob. NAHB w Mińsku, f. 1755 , op. 1, nr 33, s. 144v, 630, a 9 VI 1644 podsędka ziemskiego Ostafiego Kierdeja zastąpił podstoli wołkowyski i sędzia grodzki Adam Kołycz; zob. ibidem, f. 694, op. 4, nr 894, s. 19-19v.

${ }^{84}$ Przykładowo: pisarz, sędzia i podstarości grodzki grodzieński Mikołaj Wasiljewicz Sopoćko był bratem pisarza ziemskiego grodzieńskiego Andrzeja Wasiljewicza Sopoćki; zob. Urzędnicy Wielkiego Księstwa Litewskiego. Spisy. Województwo trockie..., s. 286; zob. też: Н. Сліж, Цудатворнь абраз Маці Божай Студэнцикай і гарадзенская шляхта: ідэнтыьфікацьяя, радаводы, сувязі, „Герольд Litherland” 2011, nr 18, s. 80, 83-84, 85-86; еadem, Лава у капліцы Маці Божай Студэникай у Фарным касцёле Гародні, „Аrсhе. Пачатак” 2010, nr 1-2(88-89), s. 90.

${ }^{85}$ Рог. Д. Вилимас, Элита и повседневность земских судов Упитского повета в 1566-1588 22. (по материалам упитских земских судов), „Соціум. Альманах соціальної історії” 2005, s. $46-47$.

${ }^{86}$ В. Галубовіч, Пастулаты Гарадзенскага сойміка на Сойм 1646 г., w: Гарадзенскі палімпсест. ХІІ-ХХ стст. Мат-ль Міжнар. навук. канф. (Горадня, 7 лістапада 2008 г.), red. А. Смаленчук, Н. Сліж, Горадня-Беласток 2008, s. 50; Акты, издаваемыь Виленской археографической комиссией..., t. 1, s. 176, 186, 188.

${ }^{87}$ NAHB w Mińsku, f. 1755, op. 1, nr 38, s. 334v. 


\section{Uposażenia starosty sądowego grodzieńskiego za Wazów}

W badanym okresie zmieniono charakter opłat sądowych pobieranych za usługi wykonywane przez starostę grodzieńskiego. Zgodnie z przywilejem króla Stefana Batorego jurgielt nowo wybranego starosty Jana Klukowskiego od 1582 r. miał zabezpieczyć ze swoich dochodów dzierżawca ożski:

до державцы ожского абы юркгел[ь]т и живность розную ему ж даваль 88.

Za Wazów starostę grodzieńskiego uposażano z dochodów ekonomii królewskiej. Świadczy o tym analiza treści listu Zygmunta III wydanego Teodorowi Skuminowi Tyszkiewiczowi 20 kwietnia 1600 r. Na trzyletnią dzierżawę starostwa grodzieńskiego, na które składało się Grodno, Horodnica, Krynki, Nowy Dwór, Lipsk, Kotra, Milkowszczyzna, Mosty, Kwasówka, Kraśnik, Odelsk, Kuźnica, Łabno oraz most przez Niemen w Grodnie, właśnie starosta ekonomiczny miał zapewnić jurgielt w wysokości 70 kop groszy litewskich Janowi Klukowskiemu ${ }^{89}$. Tymczasem brak środków niezbędnych dla utrzymania urzędów starostów sądowych zmuszał monarchę do przekazania swych dóbr stołowych w zastaw. Nieprzypadkowo starosta grodowy Jan Klukowski w latach 1593-1595 był starostą należącego do ekonomii Nowego Dworu ${ }^{90}$. Skalę opłat uzyskiwanych z czynności sądowych starosty ujawnia „Jurgielt na jurysdykcję grodzieńską" Pawła Wołłowicza z lat 1615-163091, na utrzymanie którego „dzierżawca ekonomii grodzieńskiej” miał wydać corocznie 70 kop groszy litewskich, 70 beczek żyta, 70 beczek jęczmienia i 60 beczek owsa „poki to starostwo dzierżeć będzie" ${ }^{2}$. Kontrola ekonoma grodzieńskiego na podstawie tzw. liczby należała do podskarbiego ziemskiego litewskiego $0^{93}$.

\section{Kancelaria oraz archiwum grodu grodzieńskiego}

Warto ustalić czas założenia w Grodnie kancelarii oraz archiwum - jako instytucji pomocniczych sądu i urzędu grodzkiego ${ }^{94}$. Józef Jodkowski był zdania, że:

\footnotetext{
${ }^{88}$ NAHB w Mińsku, KMf-18. Metryka WKL, nr 65, s. 157.

89 „Jurgielt Panu Klukowskiemu na Juridikę postąpiony kop litewskich siedmdziesiąth”, zob. ibidem, nr 85 , s. $84 \mathrm{v}-85 \mathrm{v}$.

${ }^{90}$ NAHB w Mińsku, f. 1755, op. 1, nr 13, s. 119-119v, 392v, 500, 608-608v, 609-609v, 610, 706v$-707,709,808,820 v, 825,861 v$. Obecnie wieś Nowy Dwór w województwie podlaskim.

${ }^{91}$ Urzędnicy Wielkiego Księstwa Litewskiego. Spisy. Województwo trockie..., s. 338.

${ }_{92}$ NAHB w Mińsku, KMf-18. Metryka WKL, nr 92, s. 39 (5 X 1615).

${ }_{93}$ Ibidem, nr 85, s. 85v; nr 92, s. 39.

${ }^{94}$ O. Balzer, Kancelarie i akta grodzkie w wieku XVIII, Lwów 1882, s. 7, 13; J. Łosowski, op. cit., s. 115.
} 
Na Zamku Starym w roku 1611 zostało urządzone archiwum na przechowywanie aktów sądu grodzkiego grodzieńskiego i kancelarja tegoż sądu ${ }^{95}$.

Jednak - o ile można sądzić - badacz ten nie miał racji. W konstytucji sejmu warszawskiego z $1611 \mathrm{r}$. Zygmunt III Waza wyraził jedynie zgodę na budowę „domu sądowego" w celu przechowywania ksiąg:

plac y mur w zamku naszym drzewianym, przy stayniach leżący, na zbudowanie domu dla sądów Ziemskich, y Grodzkich ksiąg chowania. Co sobie kosztem swym zbudować maią ${ }^{96}$.

Powstaje pytanie, czy gmach kancelarii i archiwum został zbudowany? Z pewnością w 1611 r. planowano go wystawić na terenie drewnianego zamku dolnego - górnym w tym czasie określano stary zamek - czyli na "parkanie" ${ }^{\text {" }}$.

Po raz pierwszy kancelaria grodu grodzieńskiego jest wzmiankowana w $1614 \mathrm{r}$. Latem tego roku pozew do Sądu Głównego Trybunalnego „в канцелярыи при книгах кгродских городенских" doręczono staroście grodzieńskiemu, krajczemu litewskiemu Andrzejowi Wojnie ${ }^{98}$. Mikołaj Snarski obciążył grodzieński sąd grodzki winą za zawłaszczenie łodzi i majątku ruchomego, skonfiskowanych przez woźnego powiatowego na Niemnie, a także „о непорадное выдане декрету по смерти небощыка п[а]на писара Ейсымонта [pisarza grodzkiego Wojciecha Eysymonta Żuka, zmarłego w końcu 1610 r. - A.Š. ${ }^{p 99}$.

Druga wiadomość o kancelarii grodzkiej, pochodząca z 1632 r., informuje o zabraniu przez woźnego Jana Kaszczyca na prośbę Jana Baczewskiego i jego żony Halszki Błońskiej listu wystawionego przez starostę upickiego Ostafiego Kurcza, którym poświadczał on przekazanie 3000 złotych polskich pod zastaw majątku Poniemuń (1629) ${ }^{100}$.

Przytoczone wzmianki nie dają podstaw do wnioskowania na temat lokalizacji kancelarii i archiwum grodzkiego. Wydaje się jednak, że ze względu na

95 J. Jodkowski, Grodno, Grodno 2009 (reprint), s. 33.

${ }^{96}$ Volumina Constitutionum, t. 3, cz. 1, wyd. S. Grodziski, M. Kwiecień, A. Karabowicz, Warszawa 2010, s. 38.

${ }^{97}$ Г. Семянчук, Гарадзенскія замкі ў 1578 годзе, „Краязнаўчыя запіскі” 2013, nr 9, s. 49-51, 55-60. Bez odniesienia do tej pracy opis zamku grodzieńskiego z $1578 \mathrm{r}$. opublikowała niedawno N. Sliż; zob. Н. Сліж, Гравюра Гародні Адэльгаўзера - Цюндта 1567-1568 г2. як адлюстраванне міжнародных падзей на фоне гарадскога жыция, „Arche. Пачатак” 2017, nr 2(152), s. 73-77, 79-83.

${ }^{98}$ GPMHA, nr 8245, s. 1.

${ }^{99}$ Ibidem, s. 1v; Urzędnicy Wielkiego Księstwa Litewskiego. Spisy. Województwo trockie..., s. 283. Zauważmy, że urząd grodzki grodzieński mógł być stroną (powodem lub pozwanym) w procesie wytoczonym przez Trybunał. Ze względu na „bezprawne wskazy” w 1615 r. odbyła się rozprawa, którego stronami byli podstarości Mikołaj Sopoćko i sędzia Andrzej Czyż oraz archimandryta grodzieński Kliment Godkiński; zob. Акты, издаваемые Виленской археограбической комиссией..., t. 1, s. 171-174.

${ }^{100}$ GPMHA, nr 8250, s. 1: „do kancelaryi Grodzkiey Grodzienskiey”. 
problemy finansowe budynek przy „parkanie” nie został wzniesiony. Toteż kancelaria i archiwum mieściły się nadal w jednym z pomieszczeń zamku górnego. W jednym z późniejszych opisów z lat 1650-1653 napotykamy na wzmiankę o archiwum:

sklep, gdzie sprawy kancellaryiskie chowaią, do niego drzwi na zawiasach pobielanych, zamek wnętrzny, antaba; w kącie samym drzwi dębowe $e^{101}$.

Formalnie na czele kancelarii stał starosta sądowy. Jednak w praktyce jej kierownictwo powierzano pisarzowi grodzkiemu, któremu podporządkowano podpisków. Ich liczba wahała się od jednego do kilku ${ }^{102}$. Jednym z pierwszych znanych podpisków grodu grodzieńskiego był Andrzej Grzybowski, wspomniany 28 maja 1592 r. w liście wieczystym sprzedażnym Rainy Sciepanowny Mordasowiczowej $^{103}$. W latach 1601 i 1605-1606 podpiskami grodzkimi grodzieńskimi byli Jan Zapolski oraz Wojciech Eysymont Żuk ${ }^{104}$, który w 1610 r. przez krótki czas pełnił urząd pisarza grodzkiego ${ }^{105}$. W $1621 \mathrm{r}$. wypis grodzki weryfikował z księgami grodu niejaki Suchodolski, podpisek pisarza Fiłona Kozłowickiego. Niestety jego imienia źródła nie rejestrują ${ }^{106}$.

Powstanie odrębnej grodzieńskiej kancelarii grodzkiej oraz duże obciążenie pisarza różnorodnymi sprawami natury sądowo-administracyjnej w pierwszej połowie XVII w. nie mogło pozostać bez wpływu na rozbudowanie składu grodu oraz wzrost znaczenia podpisków jako personelu pomocniczego pisarza.

${ }^{101}$ Писцовая книга Гродненской Экономии с прибавлениями, изданная Виленской комиссиею для разбора древних актов, сz. 2, Вильна 1882, s. 4. Według danych z inwentarzy zamku grodzieńskiego z lat 1680 i 1712 kancelaria $\mathrm{z}$ archiwum nie zmieniły lokalizacji; zob.: GPMHA, nr 01405, s. 4-4v; NAHB w Mińsku, f. 1761, op. 1, nr 4, s. 2-2v; Biblioteka Zakładu Narodowego im Ossolińskich, nr 5620/II, s. 5; Памяць: Гіст.-дакум. хроніка горада Гродна..., s. 100.

102 J. Łosowski, op. cit., s. 119-120, 126-127.

103 „Пан Андрей Кгрыбовский подписокъ кгродский городенский”, zob. LPAH, f. 694, ap. 1, s. 4617 v, k. 4v, 6. Kolejnym podpiskiem pisarza grodzkiego Stefana Nieszkowskiego był niejaki Jaskold, który w 1591 r. weryfikował z księgami grodzkimi wypis procesu kniazia Lwa Massalskiego; zob. NAHB w Grodnie, f. 1664, op. 1, nr 439, s. 3v: „Корикговалъ [c] книгами Яскольдь”. Zapewne chodzi o Krzysztofa Jaskolda, ziemianina powiatu grodzieńskiego (1601); zob. GPMHA, nr 9216, s. 2 (27 X 1601). W 1594 r. wypis grodzki korygował niejaki Grydzicz; zob. Archiwum Narodowe w Krakowie (dalej: ANK), Archiwum Sopoćków, sygn. 2, s. 3 v. Natomiast podpiskowie ziemscy grodzieńscy są znani od 1561 r.; zob. А. Шаланда, Дарэформенны земскі суд Гарадзенскага павета у 1562-1564 г2., w: Гарадзенскі палімпсест III. 2010..., s. 50.

${ }^{104}$ GPMHA, nr 9216, s. 2; NAHB w Mińsku, f. 1755, op. 1, nr 18, s. 85v; А. Шаланда, Радавод і герб зямян Гарадзенскага павету..., s. 25; GPMHA, nr 8732/182, s. 2 v.

${ }^{105}$ Urzędnicy Wielkiego Księstwa Litewskiego. Spisy. Województwo trockie..., s. 283. Błędnie podano go na stanowisku pisarza pod $1611 \mathrm{r}$.

${ }^{106}$ GPMHA, nr 9216/44, s. 1v. Niewykluczone, że chodzi o Łukasza Suchodolskiego, który w 1630 r. „водлуг права будучы засажоный” zastąpił podsędka ziemskiego Krzysztofa Tołłoczkę, zob. NAHB w Mińsku, f. 1755, op. 1, nr 34, s. 206v. W 1636 r. był on już komornikiem ziemskim grodzieńskim; zob. GPMHA, nr 9216, s. 2 (5 III 1636). 
Do obowiązków podpisków należało przygotowanie wypisów z ksiąg aktowych oraz ich weryfikacja, następnie dostarczanie do własnoręcznego podpisu pisarza grodzkiego, w razie nieobecności zastępowanego przez innego urzędnika grodzkiego. Na przykład w 1627 r. „в от[ъ]езде п[а]на писара за пил[ь]ным потребованем" wypis z akt został opatrzony podpisem sędziego grodzkiego Jana Sopoćki ${ }^{107}$. W 1636 r. wypis był podpisany przez innego sędziego grodu - Trojana Sułowskiego:

Jako w niebytnosci Pana Pisarza Troian Sułowski sedzia Grodzki Grodzienski ${ }^{108}$.

\section{Geneza stanowiska namiestnika powiatu grodzieńskiego}

W pierwszej połowie XVII w. w strukturze grodu grodzieńskiego pojawił się namiestnik powiatowy ${ }^{109}$, co ilustrują zapisy korygacyjne (łac. corrigo - redagować) na wypisach z ksiąg grodzkich. W 1619 r. pod nieobecność „pana podpiska" wypis dla Matysa, Ławryna, Stefana i Wasila Ciszewiczów Siezieniewiczów korygował z księgami jeden z jego pomocników, niejaki Stankiewicz ${ }^{110}$.

Spotykamy różne określenia podpisków. W źródłach z 1654 r. podpisek został nazwany namiestnikiem:

До книгъ вписанъ. Року тисеча шестьсотъ петъдесятъ четверътего м(еся)ца маръца трыдъцать перъвого дня постановивъшысе очевисто на въраде кродском гор[оденском] ег[о] м[и]л[ость $]$ ксондзъ Людвикъ Кошыцъки кгвардианъ закону Светого Франътишъка сес тестаментъ [księdza Andrzeja Kulikowskiego, plebana ożskiego - A.Š.] до актъ кгроду городенского подалъ. В небытности Пана намесника Миколай Дороневич $\mathrm{mp}^{111}$.

Nieco więcej danych o namiestnikach pochodzi z połowy XVII w. W $1645 \mathrm{r}$. urząd ten piastował komornik grodzieński Jakub Braniecki ${ }^{112}$, który tylko

${ }^{107}$ GPMHA, nr 9216, s. 1 (30 VII 1627).

${ }^{108}$ NAHB w Grodnie, f. 128, op. 1, nr 9, s. 14 (12 IX 1636).

${ }^{109}$ Prawdopodobnie stanowisko namiestnika powiatowego było odpowiednikiem starszego podpiska w województwie ruskim Królestwa Polskiego. Zgodnie z konstytucją sejmu warszawskiego 1631 r. starsi podpiskowie w grodach „wiecznych” województwa ruskiego byli zobowiązani do składania przysięgi; zob. Volumina Constitutionum, t. 3, cz. 2, wyd. S. Grodziski, M. Kwiecień, A. Karabowicz, Warszawa 2013, s. 114.

110 „В небытъности п[а]на подписка скорыкговалъ Станкевичъ mp”, zob. GPMHA, nr 8732/72, s. 1-1v. Nieobecność podpiska odnotowuje również wypis grodzki z 10 I 1624 r.: „В небытъности п(а)на подписка зкорыкговалъ [c] книгами Бялобло[цкий] mp", zob. GPMHA, nr 9216/41, s. $1 \mathrm{v}$.

111 GPMHA, nr 9216/81, s. 2v.

112 GPMHA, nr 9216/86, s. 1. Podpis o rusko-polskich cechach ortograficznych: „ЈАКуВ Бранецкий Коморник и Намесник Городенский mp". Jako Jakub Branicki, komornik grodzieński, jest wzmiankowany w 1649 r.; zob. Актьы, издаваемье Виленской археографической комиссией..., t. 1 , s. 188. 
przyjmował do aktykacji dokumenty, ale wpisywał je do ksiąg grodzkich jego pomocnik Hrehory Stanisław Zaniewski ${ }^{113}$, który w 1653 r. sam był już namiestnikiem grodzieńskim ${ }^{114}$. Wówczas dokumenty korygował $\mathrm{z}$ księgami grodzkimi jego pomocnik, nieznany z imienia Netupski ${ }^{115}$. Zakres uprawnień namiestników powiatowych nie został dotychczas zbadany. Mimo to wstępne zapoznanie się ze źródłami wskazuje, że funkcje namiestnika powiatowego nie ograniczały się do działalności pisarsko-kancelaryjnej.

W $1651 \mathrm{r}$. w źródłach wzmiankowany jest inny namiestnik, czyli namiestnik starosty bądź surogator (łac. subrogo - dodatkowo wybrany) starostwa grodzieńskiego i podstoli podlaski Jan Sławogórski, który prowadził surogackie księgi powiatu grodzieńskiego ${ }^{116}$. Mianował go na ten urząd podskarbi wielki i pisarz litewski, starosta brzeski, suraski i mścisławski, ekonom kobryński, grodzieński i mohylewski Gedeon Michał Tryzna, z czego można wnioskować, że miał do czynienia $\mathrm{z}$ administracją ekonomii grodzieńskiej, lecz nie z personelem sądu grodzkiego ${ }^{117}$. Prawdopodobnie urząd surogatora odpowiadał urzędowi zamkowego podstarościego, znanego z czasów Teodora Skumina Tyszkiewicza. W każdym razie działalność Jana Sławogórskiego świadczy o funkcjonowaniu w Grodnie w drugiej połowie XVII w. urzędu i sądu zamkowego (ekonomicznego).

Wzmianki o pomocnikach-korygatorach podpisków i namiestników grodzieńskich z pierwszej połowy XVII w. mogą świadczyć o wzroście zapotrzebowania na usługi kancelaryjno-prawne, a więc - co za tym idzie - o zwiększeniu znaczenia sądu grodzkiego po 1589 r. oraz rozbudowaniu personelu grodu - stale działającego urzędu, kancelarii i archiwum. W przeciwieństwie do składu sądu i urzędu grodzkiego, ścisłe uregulowanego przez Statut, liczba personelu kancelarii i archiwum rozrastała się w miarę zwiększania potrzeb i skali sądowo-administracyjnego obrotu dokumentacją. Można przyjąć, że uprawnienia i funkcje tej pomocniczej instytucji grodzkiej nabrały wyraźnego kształtu i treści w czasie pełnienia urzędu starosty przez Fryderyka Sapiehę w latach 1636-1650.

113 GPMHA, nr 9216/86, s. 1v. Podpisał się po polsku: „Aktykowano do Xiąg Zaniewsky mp”; zob. jeszcze jego podpis ruski: GPMHA, nr 8253, s. 1v (15 VIII 1646): „Скорыкговал Заневский”.

114 „Vstnie do tego listu Proszony Pieczętarz Hrehory Stanisław Zaniewsky Namiesnik Grodziensky mp", GPMHA, nr 9216/143, s. 1.

${ }^{115}$ Ibidem, s. 1v: „Скорыкговалъ Нетупъский mp”.

116 NAHB w Mińsku, f. 694, op. 4, nr 867, s. 28, 29. Pod wypisem z ksiąg surogackich powiatu grodzieńskiego z 20 XI 1651 r. widnieje podpis po polsku: „Jan Sławogorski Podstoli Podlasky Surogator Grodzi(e)nski mp". Jan Sławogórski był podstolim podlaskim w latach 1644-1653; zob. Urzędnicy podlascy XIV-XVIII wieku. Spisy, oprac. E. Dubas-Urwanowicz, W. Jarmolik, J. Urwanowicz, Kórnik 1994, s. 145.

${ }^{117}$ NAHB w Mińsku, f. 694, op. 4, nr 867, s. 28. 


\section{Urzędnicy grodzcy grodzieńscy w składzie sądów nadzwyczajnych: kaptury i sąd compositi iudicii}

W okresie panowania Wazów działalność sądu grodzkiego grodzieńskiego ustawała trzykrotnie: po śmierci Zygmunta III (1632) i Władysława IV (1648) oraz po abdykacji Jana Kazimierza w 1668 r. W czasie bezkrólewia powoływano sądy kapturowe $e^{118}$, w rokach których uczestniczyli również urzędnicy grodzcy ${ }^{119}$. Skład pierwszego „wazowskiego” kaptura grodzieńskiego z lat 1632-1633 nie jest znany. Jak wynika $\mathrm{z}$ wypisu z ksiąg spraw kapturowych powiatu grodzieńskiego z 4 września 1648 r., w skład drugiego sądu kapturowego weszli m.in. podstarości grodzki Adam Kołycz i pisarz Mikołaj Michał Eysymont. Pierwszy został wybrany marszałkiem, drugi zaś wykonywał obowiązki pisarza kapturowego ${ }^{120}$. Kilku kapturowych sędziów z 1648 r., np. Olbrycht Micuta, Piotr Chreptowicz oraz Andrzej Nowicki w latach 1652-1676 kontynuowało prace w grodzieńskim sądzie grodzkim, któremu przewodniczył starosta Andrzej Franciszek Kotowicz.

Najbardziej dramatyczny był okres panowania Jana Kazimierza. W konsekwencji okupacji Grodna oraz powiatu grodzieńskiego przez wojska moskiewskie w sierpniu 1655 r. prace sądu grodzkiego zostały zawieszone ${ }^{121}$. Wśród szlachty powiatowej, która w tymże roku złożyła przysięgę carowi moskiewskiemu, znaleźli się: podstarości Paweł Jurjewicz Kotowicz, sędzia grodzki Andrzej Janowicz Nowicki oraz jakiś „pisarz grodzieński” Kacper Jurjewicz Ostrowski ${ }^{122}$. Wiemy,

${ }^{118}$ Deputaci Trybunału Głównego Wielkiego Księstwa Litewskiego..., s. 205, 257; Akta zjazdów stanów Wielkiego Księstwa Litewskiego. Okresy bezkrólewi, oprac. H. Lulewicz, t. 1, Warszawa 2006, s. 315-324, 327-336. Niestety, nie udało się wykorzystać książki Andrzeja Abramskiego i Andrzeja Hurasa Sądy kapturowe (1572-1764). Studium z dziejów sq̨downictwa i prawa sądowego podczas bezkrólewi w Rzeczypospolitej szlacheckiej, Sosnowiec 2010.

${ }^{119}$ W NAHB w Mińsku zachowały się dwie księgi grodzieńskiego sądu kapturowego z lat 1668 -1669 ; zob. ibidem, f. 1870, op. 1, nr 1-2. Wypis z tych ksiąg zob. NAHB w Grodnie, f. 128, op. 1, $\mathrm{nr} 3$, s. 13-13v (2 VIII 1669). O grodzieńskich księgach kapturowych zob. 3. Антановіч, op. cit., s.64-65, 66-67, 72-73, 76-77.

${ }^{120}$ ANK, Archiwum Sopoćków, sygn. 21, s. 21-21v. W 1648 r. „на суды Капътуровые од их м[и]л[о]сти п[а]новъ обывателевъ повету Городенского [о]браными” byli marszałek Adam Kołycz, sędziowie - Stanisław Aleksandrowicz, Olbrycht Micuta, Piotr Chreptowicz, Stanisław Sopoćko, Paweł Wołłowicz, Gabriel i Dobrogost Boufałowie, Andrzej Nowicki, Andrzej Eysymont, Józef Baranowicz, Józef Grotkowski oraz pisarz Mikołaj Michał Eysymont. Wypis grodzieńskiego sądu kapturowego został spojony „печатю врадовою” starosty sądowego grodzieńskiego Fryderyka Sapiehy.

${ }^{121}$ Wzmiankę o grodzkich roczkach, które odbywały się w Grodnie jeszcze w okresie okupacji moskiewskiej, datuje się na lipiec 1655 r.; zob. NAHB w Grodnie, f. 128, op. 1, nr 5, s. 13v.

122 „Павел Юрьев сын Котовечь, подстаростья городенский, Ондрей Янов сын Новицкий, судья гроденский, Каспир Юрьев сын Островский, писарь городенский”, Крестоприводная книга шляхты Великого княжества Литовского 1655 г., red. И. Граля, орrac. Е. Лыкова, М. Кулецкий, t. 4, Москва-Варшава 1999, s. 88. 
że w 1655 r. pisarzem grodzkim był Piotr Chreptowicz ${ }^{123}$, którego na liście osób składających przysięgę nie było. Jak można przypuszczać, wspomnianego wyżej Kacpra Ostrowskiego zapisano jako piastującego urząd pisarza raczej dlatego, że był on podpiskiem pisarza ziemskiego Stanisława Sopoćki ${ }^{124}$.

Kancelaria i archiwum grodu grodzieńskiego nie zostały wywiezione z zamku, pozostając w jakimś „sklepie zamkowym”. Wiadomo także, że księgi grodzkie były prowadzone w latach 1655-1662, o czym wspomina woźny grodzieński w $1665 \mathrm{rr}^{125} \mathrm{~W}$ trakcie drugiego zajęcia Grodna przez wojska moskiewskie, w styczniu 1659 r. ${ }^{126}$, szlachta powiatowa opuściła swoje dobra, chroniąc się w lasach. Wtedy został zamordowany Andrzej Tymiński:

za Chowańskiego Moskala [kniaź Iwan Chowański, wojewoda moskiewski - A.Š.] na Czatą jego woyskowey, jz w Roku tysiąc sześćset piędziesiąt dziewiątym w Puszczy Supraslskiey ucieczką chowając się samego Jmc Pana Andrzeja Tyminskiego zamordowano, suppellectilia y sprawy wszystkie zabrano ${ }^{127}$.

Na prośbę wdowy po Andrzeju Tymińskim - Izabelli z Kołyczów - do ksiąg grodzkich grodzieńskich wniesiono zeznanie o jego śmierci oraz splądrowaniu archiwum rodowego. W 1723 r. skarbnik grodzieński Józef Tymiński ${ }^{128}$ na rozprawie dotyczącej zatargu o grunty majątku Rusota powoływał się na dwa dokumenty wystawione wówczas przez gród: ekstrakt z 15 czerwca 1660 r. wskazujący na pracę urzędu grodzkiego w tym samym czasie oraz wypis z 27 stycznia $1664 \mathrm{rr}^{129}$

Podsumowując, urząd grodzki grodzieński wraz z kancelarią działał nieprzerwanie w czasie moskiewskiej okupacji w latach 1655-1661. Co więcej, szlachta grodzieńska wysyłała do cara Aleksieja Michajłowicza swoich posłów wybranych na sejmiku „partykularnym” z prośbą o wznowienie działalności swego sądu ziemskiego i grodzkiego ${ }^{130}$. O ile wiadomo, Rosjanie pozytywnie ustosunkowali się do

${ }^{123}$ Urzędnicy Wielkiego Księstwa Litewskiego. Spisy. Województwo trockie..., s. 283.

${ }^{124}$ GPMHA, nr 9216/35, s. 3-3v. Ostrowski korygował wypis z ksiąg ziemskich grodzieńskich z 10 X 1653 r.: „Корыкговалъ с книгами Островский тр”, GPMHA, nr 9216/43, s. 1v (25 X 1654). Zob. o nim: Metryka Litewska. Księga wpisów Nr 131, oprac. A. Rachuba, Warszawa 2001, s. 80 .

${ }^{125}$ P. Borowik, Funkcjonowanie samorządu miejskiego w Grodnie podczas „potopu moskiewskiego" (1655-1661) oraz kilka uwag o zniszczeniu miasta przez Moskali, w: Гарадзенскі палімпсест. XII-XX cmcm..., s. 37.

${ }^{126}$ Ibidem, s. 29.

${ }^{127}$ NAHB w Grodnie, f. 128, op. 1, nr 5, s. 13v.

${ }^{128}$ Zajmował stanowisko skarbnika grodzieńskiego od 1724 r. Można sądzić, że w 1723 r. Józef Tymiński był skarbnikowiczem, synem Jana Kazimierza Tymińskiego, skarbnika grodzieńskiego w latach 1685-1721; zob. Urzędnicy Wielkiego Księstwa Litewskiego. Spisy. Województwo trockie..., s. 327, 329.

${ }^{129}$ NAHB w Grodnie, f. 128, op. 1, nr 5, s. 13v.

${ }^{130}$ Metryka Litewska. Księga wpisów Nr 131..., s. 228-229. 
tej prośby w maju 1657 r. ${ }^{131} \mathrm{~W}$ efekcie na przełomie lat 1657 i 1658 w Grodnie utworzono nadzwyczajny sąd compositi iudicii ${ }^{132}$. W jego skład weszli grodzieński podsędek ziemski i marszałek „судов композит[и] юдиции” Konstanty Aleksandrowicz ${ }^{133}$, pisarz ziemski Stanisław Sopoćko ${ }^{134}$, podstarości Paweł Kotowicz, sędzia Andrzej Nowicki, podczaszy i pisarz Piotr Chreptowicz ${ }^{135}$ („врадники судовые кгродские") oraz cześnik Dobrogost Bogufał (Boufał) ${ }^{136}$ i Olbrycht Jerzy Micuta - wszyscy sędziowie compositi iudicii powiatu grodzieńskiego ${ }^{137}$. W celu dopełnienia siedmioosobowego kolegium sędziowskiego podczas nieobecności podstarościego Pawła Kotowicza miał go zastępować dodatkowo obrany przez szlachtę sędzia Adam Makarewicz ${ }^{138}$. Jak widać, na grodzieński sąd „mieszany” składali się urzędnicy sądu ziemskiego i grodzkiego oraz trzech wybranych sędziów. Obradom przewodniczył marszałek sądowy. Dlatego swoim składem sąd compositi iudicii z 1658 r. przypominał sąd kapturowy.

Wpisy sądów compositi iudicii wciągano do ksiąg ziemskich grodzieńskich ${ }^{139}$, skąd wydawano wypisy z „печатью земъскою", parafowane przez marszałka sądowego i pisarza ziemskiego ${ }^{140}$. Mimo to należy je uznać za oddzielnie prowadzone księgi, ponieważ znany jest wypadek przeniesienia dokumentu z ksiąg ziemskich sądu „mieszanego” do zwykłych ksiąg ziemskich:

${ }^{131}$ С. Данскіх, Гродна у гады руска-польскай вайны 1654-1667 г2., w: Памяцьь: Гіст.-дакум. хроніка горада Гродна..., s. 82-83.

${ }^{132}$ Sąd nadzwyczajny compositi recentum criminum funkcjonował także w pow. lidzkim; zob.: A.B. Zakrzewski, Sąownictwo w Wielkim Księstwie Litewskim „pod wysoka carska ręka", w: Świat pogranicza, red. M. Nagielski, A. Rachuba, S. Górzyński, Warszawa 2003, s. 139-140; idem, Wielkie Księstwo Litewskie (XVI-XVIII w.)..., s. 212; idem, Statuty Litewskie - zasady a praktyka stosowania, w: Lietuvos Didžiosios Kunigaikštystès istorijos atodangos. Profesoriaus Mečislovo Jučo 90-mečio jubiliejui skirtas moksliniu straipsniu rinkinys, red. V. Dolinskas, R. Petrauskas, E. Rimša, Vilnius 2016, s. 283.

${ }^{133}$ Konstanty Kazimierz Aleksandrowicz, podsędek ziemski grodzieński w latach 1653-1661; zob. Urzędnicy Wielkiego Księstwa Litewskiego. Spisy. Województwo trockie..., s. 303.

${ }^{134}$ Stanisław Sopoćko zajmował stanowisko pisarza ziemskiego grodzieńskiego w latach 1653-1661; zob.: GPMHA, nr 9216/35, s. 3 (10 X 1653); Urzędnicy Wielkiego Księstwa Litewskiego. Spisy. Województwo trockie..., s. 287 (tu niesłusznie - od 1654 r.).

135 Piotr Chreptowicz piastował urząd podczaszego grodzieńskiego w latach 1652-1663. Jego żoną była Klara, córka cześnika grodzieńskiego Dobrogosta Boufała Doroszkiewicza; zob.: Urzędnicy Wielkiego Księstwa Litewskiego. Spisy. Województwo trockie..., s. 290; G. Ryżewski, Ród Chreptowiczów herbu Odrowąż, Kraków 2006, s. 218.

${ }^{136}$ Dobrogost Janowicz Boufał Doroszkiewicz był cześnikiem grodzieńskim w latach 1646-1659; zob. Urzędnicy Wielkiego Księstwa Litewskiego. Spisy. Województwo trockie..., s. 245.

${ }^{137}$ Olbrycht Jerzy Micuta jest wzmiankowany jako „судич земский городенский”; zob. NAHB w Mińsku, f. 1755, op. 1, nr 44, s. 58. Możemy z tego wnioskować, że jego ojcem był Jan Micuta, sędzia ziemski grodzieński w latach 1628-1648; zob. Urzędnicy Wielkiego Księstwa Litewskiego. Spisy. Województwo trockie..., s. 284, 322.

138 NAHB w Mińsku, f. 1755, op. 1, nr 44, s. 22 (7 I 1658), 58 (4 IV 1658), 229-229v (5 IV 1658).

${ }^{139}$ Ibidem, s. 23v, 58, 58v, 229, 229v.

${ }^{140}$ Ibidem, s. 231. 
Постановившысе очевисто его м[и]л[о]сть пан Езофъ Барановичъ выпис с книгъ земских городенских Композыты юдыцыи „переносечи его” ку актыкованю до книгъ теперешнихъ земскихъ городенских подалъ ${ }^{141}$.

Podczas okupacji miasta i zniszczeń, które dotknęly zamek w Grodnie, sąd compositi iudicii przeniesiono do Nowego Dworu ${ }^{142}$. W drugiej połowie $1659 \mathrm{r}$. sąd ten nie funkcjonował, w tym samym bowiem czasie w Grodnie wznowił pracę sąd ziemski, który odprawił michalskie roki październikowe ${ }^{143}$. Odbyły się one „водле порадку Статутового сего року о светомъ Михале Святе римскомъ припалых и судовне у Г[ор]одне одправованых"144. Z urzędu ustąpił schorowany sędzia ziemski Adam Buchowiecki, o którym w konstytucji sejmu warszawskiego $1658 \mathrm{r}$. napisano:

od lat kilku paraliżem w rękę zarażony będąc, podpisować spraw Urzędowi swemu należytych nie może ${ }^{145}$.

W 1659 r. sędzią ziemskim został wybrany dworzanin królewski Wawrzyniec Stefan Rukiewicz:

от их м[илос]тей панов обывателовъ повету городеньского водле права посполитого зъгодне обраным судею ${ }^{146}$.

W tymże czasie miał też wznowić działalność sąd grodzki. W 1659 r. jego skład uległ zmianie: pisarz grodzki Piotr Chreptowicz został podstarościm, jego miejsce zajął Olbrycht Jerzy Micuta, znany z sądu kapturowego (1648) i compositi iudicii (1658) ${ }^{147}$. Po śmierci Andrzeja Nowickiego 31 grudnia 1659 r. ${ }^{148}$ urząd sędziego grodzkiego piastował wspomniany już Wawrzyniec Stefan Rukiewicz, choć dopiero od $1661 \mathrm{r}^{149}$ Nie udało się odnaleźć ksiąg grodzkich z lat 1659-1660. Znamy jednak wzmiankę wskazującą na pracę urzędu grodzkiego grodzieńskiego.

\footnotetext{
${ }^{141}$ Ibidem, s. 229.

142 Ibidem, s. 231.

${ }^{143}$ Акты, издаваемье Виленской археографической комиссией..., t. 1, s. 86 (7 X 1659); NAНB w Mińsku f. 1755, op. 1, nr 44, s. 137 (3 X 1659), 183 (6 X 1659), 229, 231, 245, 246 (7 X 1659).

${ }^{144}$ NAHB w Mińsku, f. 1755, op. 1, nr 44, s. 261 (8 X 1659), 273 (9 X 1659).

145 Volumina Constitutionum, t. 4, cz. 1, wyd. S. Grodziski, M. Kwiecień, K. Fokt, Warszawa 2015, s. 410 .

${ }^{146}$ NAHB w Mińsku, f. 1755, op. 1, nr 44, s. 261, 273; Акты, издаваемые Виленской археограбической комиссией..., t. 1, s. 86.

147 Urzędnicy Wielkiego Księstwa Litewskiego. Spisy. Województwo trockie..., s. 284, 307; NAHB w Mińsku, f. 1711, op. 1, nr 187, s. 9, 9v: 7 VII 1659 r. na urzędzie „господарском кгродском городенском” byli podczaszy i podstarości grodzieński Piotr Chreptowicz, „засаджаны” przez pisarza litewskiego, starostę grodzieńskiego i horodniczego wileńskiego Andrzeja Kotowicza, a także pisarz grodzki Olbrycht Micuta.

148 Urzędnicy Wielkiego Księstwa Litewskiego. Spisy. Województwo trockie..., s. 317.

${ }^{149}$ Ibidem.
} 
Dowodzi tego wypis z jego ksiąg aktowych datowany 22 lipca 1659 r. z protestacją rozprawy sądowej ojca Filipa Kosińskiego, duchownego z cerkwi w Kozłowiczach $^{150}$. W tym samym czasie więzienie w zamku górnym było wykorzystywane przez sąd ziemski na własne potrzeby ${ }^{151}$.

\section{Wznowienie prac sądu grodzkiego grodzieńskiego w latach 1661-1668}

Wiadomo dokładnie, że na początku września 1660 r., wraz z rozpoczęciem oblężenia garnizonu moskiewskiego na zamku grodzieńskim, sąd grodzki nie funkcjonowa ${ }^{152}$. Grodno zostało wyzwolone w marcu 1661 r., gdy szlachta dowodzona przez marszałka powiatowego Krzysztofa Buchowieckiego wyparła nieprzyjaciela $\mathrm{z}$ zamku ${ }^{153}$. O ówczesnym stanie miasta informuje konstytucja sejmowa $\mathrm{z}$ tegoż $1661 \mathrm{r} .:$

miasto Grodzieńskie z folwarkami, y przedmieściami od woysk Moskiewskich zgruntu zruinowane y spustoszone zostaie ${ }^{154}$.

Król Jan Kazimierz w swoim liście podkreślił, że po wydarzeniach wojennych zamek górny w Grodnie, pozbawiony dachu, wymagał gruntownej restauracji ${ }^{155}$. Ze względu na to sądy ziemskie i grodzkie musiały zmienić miejsce odbywania roczków. W październiku 1664 r. generał powiatu grodzieńskiego Aleksander Soroka zaznaczył, że odbywano je w jakiejś „izbie sądowej” w mieście:

w miescie JKMsci Grodzienskim w Jzbie Sądowey gdzie się na ten czas Sądy Ziemskie Grodzienskie odprawowali ${ }^{156}$.

Pozostaje jednak pytanie: czy we wspomnianej izbie, której lokalizacji nie podano, odbywały się też roki sądu grodzkiego?

Nominacja podstarościego i cześnika grodzieńskiego Piotra Chreptowicza w 1663 r. na stanowisko pisarza ziemskiego ${ }^{157}$ pociągała za sobą kolejne ruchy kadrowe w sądzie grodzkim. Zgodnie z decyzją starosty Andrzeja Kotowicza urząd podstarościego zajął pisarz grodzki Olbrycht Micuta. Pisarzem grodzkim został natomiast skarbnik smoleński Aleksander Sopoćko. Jedynie Wawrzyniec

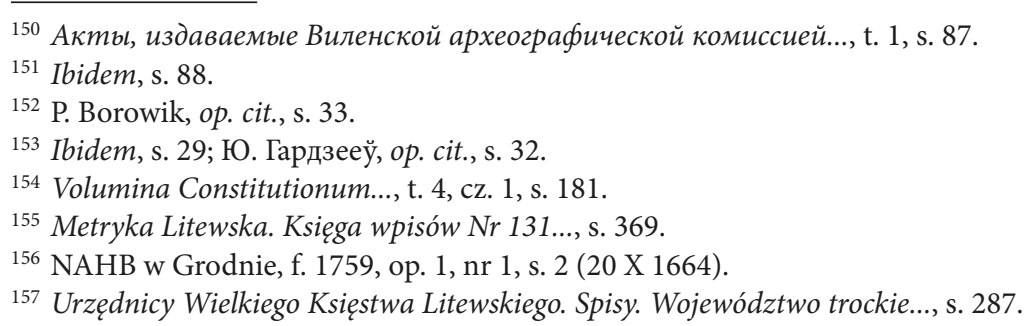


Rukiewicz nadal pełnił urząd sędziego ${ }^{158}$. Latem 1665 r. rozstrzygali oni w takim składzie spór między pisarzem grodzieńskiej komory celnej Andrzejem Michałem Mołodziłą a podczaszym upickim Andrzejem Kazimierzem Gruszczyńskim ${ }^{159}$. Efektem „ekscesu”, do którego doszło w grodzieńskim „domu skarbowym”, było pozwanie podczaszego do sądu grodzkiego na roczki czerwcowe ${ }^{160}$. Andrzej Gruszczyński, który nie wpuścił woźnego z pozwem do swego majątku Łosośna, tłumaczył się przed sądem grodzkim pomówieniem go przez Andrzeja Mołodziłę oraz tym, że on sam nie wszczynał żadnego zatargu. Szczególny nacisk kładł na to, że w domu skarbowym przebywał nie z własnej woli, lecz w związku ze sprawą administratora ceł Wielkiego Księstwa Henryka Monesa. Stąd Gruszczyński próbował przekonać urzędników grodu:

Aże mię niesłusznie turbuie P.: Mołodziło rad bym niewinność moie przed sądem [...] pokazać161.

W drugiej połowie XVII w. obok namiestnika w grodzie grodzieńskim pojawił się regent. Wzmianki o regencie grodzkiej kancelarii grodzieńskiej świadczą o tym, że jej skład (namiestnik, regent, podpiskowie) ostatecznie ukształtował się w okresie pełnienia urzędu starosty przez Andrzeja Franciszka Kotowicza (1652-1676). Można przypuszczać, że do jej grona należał podpisek Jerzy Budkiewicz, wzmiankowany w latach $1668-169^{162}$. Funkcjonowanie regenta może oznaczać również to, że księgi grodzkie grodzieńskie nabierały charakteru ksiąg wieczystych. Jedna z takich ksiąg zachowała się z zbiorach Narodowego Archiwum Historycznego Białorusi w Mińsku. 24 stycznia 1667 r. podstarości grodzieński Olbrycht Micuta wniósł do ksiąg aktykację listu Gabriela Olbrachtowicza Garbowskiego ${ }^{163}$.

Jan Kazimierz abdykował 16 września 1668 r. Zatem 5 listopada na konwokacji w Warszawie, w której z ramienia powiatu grodzieńskiego uczestniczyli starosta grodzieński Andrzej Franciszek Kotowicz i Kazimierz Stanisław Chreptowicz, uchwalono konfederację generalną ${ }^{164}$. Zgodnie z nią podczas kapturów, kiedy działalność sądów grodzkich była zawieszana, księgi aktowe nadal miały być udostępniane:

158 Ibidem, s. 284, 307, 317. Aleksander Sopoćko był skarbnikiem smoleńskim nie tylko w latach 1687-1705, lecz także w 1663 r.; zob. Urzędnicy Wielkiego Księstwa Litewskiego. Spisy. Ziemia smoleńska i województwo smoleńskie. XIV-XVIII wiek, t. 4, red. A. Rachuba, oprac. H. Lulewicz, A. Rachuba, P. Romaniuk, Warszawa 2003, s. 170.

${ }^{159}$ Według znanych źródeł Andrzej Kazimierz Gruszczyński piastował urząd podczaszego upickiego w latach 1674-1693; zob. Urzędnicy Wielkiego Księstwa Litewskiego. Spisy. Województwo trockie..., s. 492.

${ }^{160}$ GPMHA, nr 9216, s. 1 (8 VI 1665).

${ }^{161}$ Ibidem (7 VI 1665).

162 3. Антановіч, op. cit., s. 75.

${ }^{163}$ NAHB w Mińsku, f. 1711, op. 1, nr 214, s. 1-2v.

164 Volumina Constitutionum, t. 4, cz. 2, wyd. S. Grodziski, M. Kwiecień, K. Fokt, Warszawa 2017, s. $380-381$. 
Urząd Grodzki one [księgi aktowe - A.Š.] otworzyć y każdemu do nich wolny przystęp dawać $\mathrm{ma}^{165}$.

Od początku listopada $1668 \mathrm{r}$. w powiecie grodzieńskim działał tutejszy sąd kapturowy, w skład którego weszli dwaj urzędnicy grodzcy: sędzia Wawrzyniec Rukiewicz oraz pisarz Aleksander Sopoćko. Właśnie oni zostali wybrani w celu przeprowadzenia śledztwa (skrutynium) w sprawie archimandryty grodzieńskiego księcia Mitrofana Druckiego Sokolońskiego ${ }^{166}$.

Podsumowując, działalność sądu grodzkiego grodzieńskiego w okresie panowania Wazów opierała się na normach III Statutu litewskiego wdrożonych jeszcze przez przedwazowski skład grodu, czyli starostę Jana Wasiljewicza Klukowskiego, podstarościego Węcława Wdanowskiego, sędziego Sołujana Bogufała Doroszkiewicza oraz pisarza Stefana Nieszkowskiego. Za panowania Zygmunta III wprowadzono nowe zasady i uposażenie grodzieńskiego starosty sądowego. Na jego jurgielt składały się dochody ekonomii grodzieńskiej. Uposażenie starosty spoczywało na barkach dzierżawcy - ekonoma lub starosty ekonomicznego, którym w latach 1589-1618 był Teodor Skumin Tyszkiewicz.

W pewnym stopniu można mówić o wzroście prestiżu urzędników grodzkich powiatu grodzieńskiego w oczach szlachty, ponieważ według nowej hierarchii urzędów powiatowych zajmowali oni miejsce za pisarzem ziemskim. Piastowanie urzędów grodzkich pozwalało na awans w strukturach samorządu szlacheckiego oraz instytucjach władzy centralnej. Stopień pokrewieństwa oraz powinowactwa, stosunków służbowych oraz koleżeńskich z urzędnikami ziemskimi sprzyjał formowaniu się w powiecie grodzieńskim specyficznej korporacji zawodowej, stanowiącej część elit powiatowych.

Sąd i urząd grodzki w Grodnie mieścił się w górnym zamku, gdzie znajdowały się izba sądowa, więzienie, kancelaria oraz archiwum. Na potrzeby dwóch ostatnich instytucji w $1611 \mathrm{r}$. Zygmunt III Waza wyraził zgodę na budowę specjalnego „domu sądowego” na zamku dolnym („parkanie”). Plan ten nie doczekał się jednak realizacji. Zresztą w okresie późniejszym kancelaria i archiwum znajdowały się w zamku górnym („sklepie zamkowym”). Po raz pierwszy grodzieńska kancelaria grodzka została wzmiankowana w okresie pełnienia urzędu starosty przez Andrzeja Wojnę (1602-1615). Ze względu na wzrost zapotrzebowania na usługi prawne oraz rozbudowanie składu kancelarii w grodzie pojawił się namiestnik powiatu grodzieńskiego, o którym wspominają źródła z 1645 r. Lokalizacja, funkcje i kompetencje kancelarii zostały określone za starosty Fryderyka Sapiehy w latach 1636-1650.

W okresie panowania Wazów działalność sądu grodzkiego grodzieńskiego ustawała trzykrotnie: w 1632 r. po śmierci Zygmunta III, w 1648 r. po śmierci

\footnotetext{
165 Ibidem, s. 359.

166 3. Антановіч, ор. сіt., s. 75; Акты, издаваемые Виленской археографической комиссией..., t. 1 , s. 339-340.
} 
Władysława IV oraz w 1668 r. po abdykacji Jana Kazimierza. W czasie bezkrólewia powoływano sądy kapturowe, w pracach których uczestniczyli urzędnicy grodu grodzieńskiego. W latach 1655-1661 Grodno było okupowane przez wojska moskiewskie. Miejscowi urzędnicy grodzcy w niemal pełnym składzie złożyli przysięgę carowi Aleksiejowi Michajłowiczowi Romanowowi. Dlatego urząd i kancelaria grodzka kontynuowały swoje prace podczas całej okupacji miasta. Ponadto - nie bez carskiej aprobaty - od $1658 \mathrm{r}$. w powiecie grodzieńskim funkcjonował nadzwyczajny sąd compositi iudicii, w składzie 6 sędziów i marszałek. Widzimy w nim również urzędników grodzkich - podstarościego Pawła Kotowicza, sędziego Andrzeja Nowickiego i pisarza Piotra Chreptowicza. Z powodu okupacji i zniszczeń, które dotknęły górny zamek w Grodnie, sąd ten przeniesiono z Grodna do Nowego Dworu. W latach 1659-1661 skład sądu grodzkiego grodzieńskiego został odnowiony, pozbyto się sędziów kapturowych oraz compositi iudicii. Przed abdykacją Jana Kazimierza w 1668 r. urzędnikami grodu byli podstarości Olbrycht Micuta, sędzia Wawrzyniec Rukiewicz oraz pisarz Aleksander Sopoćko. Po abdykacji monarchy, od początku listopada $1668 \mathrm{r}$. w powiecie grodzieńskim działał sąd kapturowy, skład którego zasilili dwaj urzędnicy grodzcy - sędzia Wawrzyniec Rukiewicz i pisarz Aleksander Sopoćko.

\section{Streszczenie}

Działalność sądu grodzkiego grodzieńskiego w okresie panowania Wazów opierała się na normach III Statutu Wielkiego Księstwa Litewskiego z 1588 r. Za panowania Zygmunta III wprowadzono nowe zasady i wysokość opłat dla grodzieńskiego starosty sądowego, pochodzące z dochodów ekonomii grodzieńskiej. Uposażenie starosty spoczywało na barkach dzierżawcy-ekonoma lub starosty ekonomicznego. Można mówić o wzroście prestiżu urzędników grodzkich powiatu grodzieńskiego. Fakt piastowania urzędów grodzkich stwarzał możliwość awansu w strukturach samorządu szlacheckiego i władzy centralnej. Sąd i urząd grodzki w Grodnie mieścił się w górnym zamku, gdzie znajdowały się izba sądowa, więzienie, kancelaria i archiwum. Po raz pierwszy grodzieńska kancelaria grodzka została wzmiankowana w okresie pełnienia urzędu starosty przez Andrzeja Wojnę (1602-1615). Ze względu na wzrost zapotrzebowania na usługi prawne oraz rozbudowanie składu kancelarii w grodzie pojawił się namiestnik powiatu grodzieńskiego. Lokalizacja, funkcje i kompetencje kancelarii kompletnie zostały określone za starosty Fryderyka Sapiehy w latach 1636-1650. W czasie bezkrólewia powoływano sądy kapturowe, w których sądzili również urzędnicy grodu grodzieńskiego. W latach 1655-1661, kiedy Grodno było okupowane przez wojska moskiewskie, urząd i kancelaria grodzka kontynuowały działalność. Od 1658 r. w powiecie grodzieńskim funkcjonował nadzwyczajny sąd compositi iudicii, w składzie 6 sędziów i marszałek, wśród których znaleźli się urzędnicy grodzcy. W latach 1659-1661 skład sądu grodzkiego grodzieńskiego został odnowiony, pozbyto się sędziów kapturowych oraz compositi iudicii. 


\section{The Grodno (Hrodna) Castle Court in the Vasa Period (1587-1668): The State of Research and Sources Summary}

The activity of the Grodno castle court during the reign of the Vasa dynasty was based on the norms of the Third Statute of the Grand Duchy of Lithuania of 1588. During the period of King Sigismund III, new rules and the scope of work of the castle starost (capitaneus castrensis) were introduced. His fees consisted of income from the Grodno royal domain estate (ekonomia). The castle starost's payment rested on the shoulders of a leaseholder of the domain or the starost of the Grodno domain estate. We can talk about the increase in the prestige of castle court officials in the district (powiat) of Grodno in the eyes of the nobility. The fact of holding castle court offices conditioned the possibility of promotion within the structures of the nobility's self-government and central institutions. The castle court in Grodno was located in the upper castle, where there was a courthouse, a prison, and a chancellery with archive. For the first time, the chancellery was mentioned during the period of Andrzej Wojna (1602-1615). Due to the increase in demand for legal services and the growing number of the chancellery officials, the office of lord-lieutenant (namiestnik) of the Grodno district was established. The location, functions and scope of authority of the chancellery were finally determined during the period of Fryderyk Sapieha in 1636-1650. During the interregnum, the so-called hooded courts (sady kapturowe) were appointed, in which the officials of the Grodno castle court participated. In the years 1655-1661, when Grodno was occupied by the Muscovite army, the castle office (officium castrensis) and the chancellery continued working. From 1658 on, in the Grodno district there was an extraordinary court of compositi iudicia made up of six judges and a marshal, from among the castle officials. In the years 1659-1661, the composition of the Grodno castle court was renewed at the expense of the 'hooded courts' and compositi iudicia judges.

\section{Bibliografia}

\section{Źródła drukowane}

Akta zjazdów stanów Wielkiego Księstwa Litewskiego. Okresy bezkrólewi, oprac. H. Lulewicz, t. 1, Warszawa 2006.

Metryka Litewska. Księga wpisów Nr 131, oprac. A. Rachuba, Warszawa 2001.

Monumentum virtuti meritissimae Perillustris et Magnifici Herois D[omini] Theodori Tiskiewicz Skumin Palatini Novogroden[sis], Grodnensis, Olyten[sis], Iurburgen[sis], Novowolensis Capitanei..., Vilnae [1618].

Volumina Constitutionum, t. 2, cz. 2, wyd. S. Grodziski, Warszawa 2008; t. 3, cz. 1-2, wyd. S. Grodziski, M. Kwiecień, A. Karabowicz, Warszawa 2010-2013; t. 4, cz. 1-2, wyd. S. Grodziski, M. Kwiecień, K. Fokt, Warszawa 2015-2017.

Акты, издаваемые Виленской археографической комиссией, t. 1, 2, 7, 31, Вильна 1865, 1867, $1874,1906$.

Актьи, относящиеся к истории Западной России (1588-1632), t. 4, Санкт-Петербург 1851.

Крестоприводная книга иляхты Великого княжества Литовского 1655 г., red. И. Граля, орrac.

Е. Лыкова, М. Кулецкий, t. 4, Москва-Варшава 1999.

Писцовая книга Гродненской Экономии с прибавлениями, изданная Виленской комиссиею для разбора древних актов, сz. 2, Вильна 1882.

Статут Вялікага Княства Літоўскага 1588. Тэксты. Даведнік. Каментарыі, red. І. Шамякін et al., Мінск 1989. 


\section{Opracowania}

Balzer O., Kancelarie i akta grodzkie w wieku XVIII, Lwów 1882.

Borowik P., Funkcjonowanie samorządu miejskiego w Grodnie podczas "potopu moskiewskiego" (1655-1661) oraz kilka uwag o zniszczeniu miasta przez Moskali, w: Гарадзенскі палімпсест. XII-XX cтст. Мат-ль Міжнар. навук. канф. (Горадня, 7 лістапада 2008 г.), red. А. Смаленчук, Н. Сліж, Горадня-Беласток 2008, s. 29-39.

Deputaci Trybunału Głównego Wielkiego Księstwa Litewskiego (1582-1696). Spis, red. A. Rachuba, oprac. H. Lulewicz, A. Rachuba, Warszawa 2007.

Jodkowski J., Grodno, Grodno 2009 (reprint).

Lulewicz H., Gniewów o unię ciąg dalszy. Stosunki polsko-litewskie w latach 1569-1588, Warszawa 2002.

Łosowski J., Kancelaria grodzka chełmska od XV do XVIII wieku. Studium o urzędzie, dokumentacji, jej formach i roli w życiu społeczeństwa staropolskiego, Lublin 2004.

Moniuszko A., Mazowieckie sądy ziemskie (1588-1648). Organizacja-funkcjonowanie - postępowanie, Warszawa 2013.

Moniuszko A., Sędziowie sądów szlacheckich w województwie płockim 1576-1600. Próba rekonesansu badawczego, „Studia z Dziejów Państwa i Prawa Polskiego” 19, 2016, s. 39-67.

Ryżewski G., Ród Chreptowiczów herbu Odrowąż, Kraków 2006.

Urzędnicy centralni i dostojnicy Wielkiego Księstwa Litewskiego XIV-XVIII wieku. Spisy, oprac. H. Lulewicz, A. Rachuba, Kórnik 1994.

Urzędnicy podlascy XIV-XVIII wieku. Spisy, oprac. E. Dubas-Urwanowicz, W. Jarmolik, J. Urwanowicz, Kórnik 1994.

Urzędnicy Wielkiego Księstwa Litewskiego. Spisy. Województwo trockie XIV-XVIII wiek, t. 2, red. A. Rachuba, oprac. H. Lulewicz et al., Warszawa 2009.

Urzędnicy Wielkiego Księstwa Litewskiego. Spisy. Ziemia smoleńska i województwo smoleńskie. XIV-XVIII wiek, t. 4, red. A. Rachuba, oprac. H. Lulewicz, A. Rachuba, P. Romaniuk, Warszawa 2003.

Zakrzewski A.B., Sadownictwo w Wielkim Księstwie Litewskim „pod wysoką carską ręką”, w: Świat pogranicza, red. M. Nagielski, A. Rachuba, S. Górzyński, Warszawa 2003, s. 137-141.

Zakrzewski A.B., Statuty Litewskie - zasady a praktyka stosowania, w: Lietuvos Didžiosios Kunigaikštystès istorijos atodangos. Profesoriaus Mečislovo Jučo 90-mečio jubiliejui skirtas moksliniu straipsniu rinkinys, red. V. Dolinskas, R. Petrauskas, E. Rimša, Vilnius 2016, s. 279-291.

Zakrzewski A.B., Wielkie Księstwo Litewskie (XVI-XVIII w.). Prawo - ustrój - społeczeństwo, Warszawa 2013.

Антановіч 3., Гарадзенскі каптуровы суд у XVII-XVIII стст., w: Гарадзенскі палімпсест III. 2010. Дзяржаўныя і сацыяльныя структуры. XVI-XX стст., red. А. Смаленчук, Н. Сліж, Мінск 2011, s. 57-83.

Вилимас Д., Элита и повседневность земских судов Упитского повета в 1566-1588 г2. (по материалам упитских земских судов), „Соціум. Альманах соціальної історії” 2005, nr 5, s. 41-50.

Галубовіч В., Пастулаты Гарадзенскага сойміка на Сойм 1646 г., w: Гарадзенскі палімпсест. XII-XX стст. Мат-лы Міжнар. навук. канб. (Горадня, 7 лістапада 2008 г.), red. А. Смаленчук, Н. Сліж, Горадня-Беласток 2008, s. 48-53.

Галубовіч В., Справа пра напад на гарадзенскі клящтар францысканцаў у 1645 г., w: Гарадзенскі палімпсест II. 2009. Дзяржаўныя ўстановы і палітычнае жыциё. XV-XX cmст., red. А. Смаленчук, Н. Сліж, Горадня 2009, s. 253-258.

Гардзееў Ю., Магдэбургская Гародня, Гародня-Wrocław 2008. 
Грыцкевіч А., Тыцкевічы, w: Вялікае Княства Літоўскае. Энцыклапедыя, t. 2, wуd. 2, Мінск 2007, s. 681-682.

Данскіх С., Гродна у гады руска-польскай вайны 1654-1667 г2., w: Памяць: Гіст.-дакум. хроніка горада Гродна, red. Г. Пашкоў, Я. Жабрун, І. Крэнь et al., Мінск 1999, s. 82-84.

Данскіх С., Гродна ў час Паўночнай вайны 1700-1721 г2., w: Памяцьв: Гіст.-дакум. хроніка горада Гродна, red. Г. Пашкоў, Я. Жабрун, I. Крэнь et al., Мінск 1999, s. 97-99.

Іванова Л., Гарадзенскі земскі суд у канцы XVI cm. У кантэксие Статутаў Вялікага Княства Літоўскага 1566 i 1588 г2., „Arche. Пачатак” 2014, nr 11(132), s. 106-121.

Лаппо И., Гродский суд в Великом княжестве Литовском в XVI столетии, „Журнал Министерства Народного Просвещения" n.s. 13, 1908, nr 1, dz. 2, s. 51-113.

Падалінскі У., Крыштоф Дарагастайскі - пасол на соймы Рэчы Паспалітай (1587-1596 гz.), w: Ашмяншчына. Праблемы рэгіянальнай гісторыі Беларусі: зб. навук. арт., red. А. Каваленя et al., Мінск 2011, s. 136-149.

Поліщук В., Офічійні свідкі в структурі Луцъького замкового уряду до реформ 1564-1566 років (службове підпорядкування і правові послуги), Київ 2003.

Семянчук Г., Гарадзенскія замкі у 1578 годзе, „Краязнаўчыя запіскі” 2013, nr 9, s. 44-62.

Сліж Н., Гарадзенскія падворкі XVII cm., w: Гарадзенскі палімпсест III. 2010. Дзяржаўныя i сацыяльныя структуры. XVI-XX стст., red. А. Смаленчук, Н. Сліж, Мінск 2011, s. 222-254.

Сліж Н., Гравюра Гародні Адэльгаўзера - Цюндта 1567-1568 гг. якадлюстраванне міжнародных падзей на фоне гарадскога жыция, „Аrсhе. Пачатак” 2017, nr 2(152), s. 9-105.

Сліж Н., Лава ў капліцы Маці Божай Студэникай у Фарным касиёле Гародні, „Аrсhе. Пачатак” 2010, nr 1-2(88-89), s. 66-97.

Сліж Н., Цудатворны абраз Маці Божай Студэнцкай і гарадзенская шляхта: ідэнтыфбікацыья, радаводы, сувязі, „Герольд Litherland” 2011, nr 18, s. 47-93.

Шаланда А., Антоні дэ Кгрып - муляр гарадзенскага замка $і$ яго род у канцы XVI - першай палове XVII cm., „Краязнаўчыя запіскі” 2012, nr 8, s. 17-26.

Шаланда А., Гродскі суд Гарадзенскага павета ВКЛ у другой палове XVI-XVII cmcm. Частка I: Перадумовы, ход і вынікі рэформы гарадзенскага замкавага суда (1562-1572 г2.), w: Гарадзенскі палімпсест III. 2010. Дзяржаўныя і сацыяльныя структуры. XVI-XX cmcm., red. А. Смаленчук, Н. Сліж, Мінск 2011, s. 12-44.

Шаланда А., Гродскі суд Гарадзенскага павета у другой палове XVI-XVII cmст. Частка II: Функиььянаванне гарадзенскага гродскага суда у перыяд першых бескаралеўяу у 1572-1576 г2., w: Гарадзенскі палімпсест IV. 2011. Асоба, грамадства, дзяржава. XV-XX стст., red. А. Смаленчук, Н. Сліж, Мінск 2012, s. 112-134.

Шаланда А., Гродскі суд Гарадзенскага павета ВКЛ у часы праўлення Стэфана Баторыя (1576-1586 г2.), w: Вялікае Княства Літоўскае і суседзі. Права, вайна, дыпламатыя, red. С. Сокал, А. Янушкевіч, Мінск 2012, s. 44-82.

Шаланда А., Дарэформенны земскі суд Гарадзенскага павета у 1562-1564 г2., w: Гарадзенскі палімпсест III. 2010. Дзяржаўныя і сацыяльныя структуры. XVI-XX cmcm., red. А. Смаленчук, Н. Сліж, Мінск 2011, s. 45-56.

Шаланда А., Замкавы суд у Гарадзенскім павеще (другая палова XV-1566 г.), w: Гарадзенскі палімпсест II. 2009. Дзяржаўныя ўстановы і палітычнае жыциё. XV-XX cmcm., red. А. Смаленчук, Н. Сліж, Горадня 2009, s. 8-34.

Шаланда А., Радавод і герб зямян Гарадзенскага павету Пуиіўлянінаў Свяикіх у другой палове XVI-XVIII cm., „Герольд Litherland” 2001, nr 1, s. 7-27.

Шаланда А., Род Антонія дэ Кгрыпа, муляра замка Гарадзенскага ў канцы XVI - першай палове XVII cm., w: Castrum, urbs et bellum. 36. навук. прач, Баранавічы 2002, s. 402-412. 
Alaksiej Šałanda (Аляксей Шаланда, Aliaksej Shalanda) - kandydat nauk historycznych, docent, kierownik Oddziału Genealogii, Heraldyki i Numizmatyki Instytutu Historii Narodowej Akademii Nauk Białorusi w Mińsku. Specjalizuje się w historii, heraldyce i sfragistyce Wielkiego Księstwa Litewskiego i Białorusi oraz w edytorstwie. E-mail: litherland@tut.by 